\title{
Structural and functional control of surface-patch to hillslope runoff and sediment connectivity in Mediterranean dry reclaimed slope systems
}

\author{
Mariano Moreno-de-las-Heras ${ }^{1,2}$, Luis Merino-Martín ${ }^{3,4}$, Patricia M. Saco ${ }^{5,6}$, Tíscar Espigares ${ }^{7}$, Francesc Gallart ${ }^{1}$, \\ and José M. Nicolau ${ }^{8,9}$ \\ ${ }^{1}$ Institute of Environmental Assessment and Water Research (IDAEA, CSIC), 08034 Barcelona, Spain \\ ${ }^{2}$ Desertification Research Centre (CIDE, CSIC-UV-GV), 46113 Moncada, Valencia, Spain \\ ${ }^{3}$ University of Montpellier, AMAP, INRAE, CIRAD, CNRS, IRD, PS2 TA/A51, 34398 Montpellier CEDEX 5, France \\ ${ }^{4}$ CEFE, Univ. Montpellier, CNRS, EPHE, IRD, Univ. Paul Valéry, Montpellier, France \\ ${ }^{5}$ Civil, Surveying and Environmental Engineering, The University of Newcastle, 2308 Callaghan, New South Wales, Australia \\ ${ }^{6}$ Centre for Water Security and Environmental Sustainability, The University of Newcastle, \\ 2308 Callaghan, New South Wales, Australia \\ ${ }^{7}$ Department of Life Sciences, Faculty of Sciences, University of Alcalá, 28805 Alcalá de Henares, Madrid, Spain \\ ${ }^{8}$ Department of Agrarian and Environmental Sciences, Technological School, University of Zaragoza, 22071 Huesca, Spain \\ ${ }^{9}$ Environmental Sciences Institute of Aragon, University of Zaragoza, 50009 Zaragoza, Spain
}

Correspondence: Mariano Moreno-de-las-Heras (mariano.moreno@idaea.csic.es)

Received: 24 October 2019 - Discussion started: 2 January 2020

Revised: 12 April 2020 - Accepted: 24 April 2020 - Published: 29 May 2020

\begin{abstract}
Connectivity has emerged as a useful concept for exploring the movement of water and sediments between landscape locations and across spatial scales. In this study, we examine the structural and functional controls of surfacepatch to hillslope runoff and sediment connectivity in three Mediterranean dry reclaimed mining slope systems that have different long-term development levels of vegetation and rill networks. Structural connectivity was assessed using flow path analysis of coupled vegetation distribution and surface topography, providing field indicators of the extent to which surface patches that facilitate runoff and sediment production are physically linked to one another in the studied hillslopes. Functional connectivity was calculated using the ratio of patch-scale to hillslope-scale observations of runoff and sediment yield for 21 monitored hydrologically active rainfall events. The impact of the dynamic interactions between rainfall conditions and structural connectivity on functional connectivity were further analysed using general linear models with a backward model structure selection approach. Functional runoff connectivity during precipitation events was found to be dynamically controlled by antecedent
\end{abstract}

precipitation conditions and rainfall intensity and strongly modulated by the structural connectivity of the slopes. On slopes without rills, both runoff and sediments for all events were largely redistributed within the analysed hillslopes, resulting in low functional connectivity. Sediment connectivity increased with rainfall intensity, particularly in the presence of rill networks where active incision under high-intensity storm conditions led to large non-linear increases in sediment yield from the surface-patch to the hillslope scales. Overall, our results demonstrate the usefulness of applying structuraland functional-connectivity metrics for practical applications and for assessing the complex links and controlling factors that regulate the transference of both surface water and sediments across different landscape scales.

\section{Introduction}

Surface processes in Mediterranean landscapes are affected by multiple factors (e.g. rainfall characteristics, soil surface properties, vegetation, micro-topography and landforms) that 
interact at a variety of spatial scales (from the surface-patch to the plot, hillslope and catchment scales), resulting in intricate responses of runoff and sediment yield (Puigdefabregas et al., 1999; Calvo-Cases et al., 2003; Cammeraat, 2004; Yair and Raz-Yassif, 2004; Boix-Fayos et al., 2006; Morenode-las-Heras et al., 2010; Mayor et al., 2011; Gallart et al., 2013; Marchamalo et al., 2016). In these complex systems, connectivity has emerged as a useful concept for studying the movement and transference of surface water and water-borne materials (e.g. sediments, nutrients and seeds) between landscape locations or scales (Bracken and Croke, 2007; Wainwright et al., 2011; Bracken et al., 2013; Reaney et al., 2014; Keesstra et al., 2018; Saco et al., 2020).

Two conceptual elements of hydrological connectivity that facilitate the analysis of the spatial and temporal dynamics of both runoff and sediments throughout hillslopes and catchments were proposed: structural and functional connectivity (Turnbull et al., 2008; Wainwright et al., 2011; Okin et al., 2015). Structural connectivity refers to the spatial arrangement of hydrologically significant units or elements, and it captures the extent to which these units are physically linked to each other in order to allow for the transfer of water and sediments. The second, functional (or process-based; Bracken et al., 2013) connectivity, refers to the activation of connections of runoff and/or sediment pathways during a particular rainfall event. Functional connectivity of runoff depends on the dynamics of overland flow generation, routing and downward re-infiltration. For sediments, functional connectivity is a function of the detachment, entrainment, deposition and remobilization of sediments across scales (Wainwright et al., 2011; Bracken et al., 2013; Turnbull and Wainwright, 2019).

Multiple studies have focused on the analysis of the effects of landscape structural components of connectivity on runoff and soil erosion, particularly in Mediterranean dry and other dryland systems. In water-limited environments with patchy vegetation, measures related to the spatial organization (i.e. the pattern, patch size and landscape position) of vegetation explain runoff and soil erosion better than average vegetation cover (Bautista et al., 2007; Arnau-Rosalén et al., 2008; Puigdefabregas, 2005). The spatial arrangement of surface features (e.g. vegetation cover, rills, gullies, channels and terraces) were shown to control the distribution of source and sink elements in these landscapes from a structuralconnectivity perspective, largely driving the production and transference of water and sediments across scales (Cammeraat, 2004; Turnbull et al., 2010; Merino-Martín et al., 2015; Marchamalo et al., 2016; Moreno-de-las-Heras et al., 2019). Structural connectivity can be highly dynamic over long time periods (e.g. decades or longer) as a result of changes in vegetation, land use and surface morphology. However, structural connectivity is generally considered a static landscape feature over the time periods of interest (e.g. the hydrological year), which has facilitated the application of this concept in hydrological and geomorphological studies using surface contiguity indexes (Heckmann et al., 2018, and references therein).

The interactions between precipitation conditions and the structural connectivity of a landscape determine functional connectivity (Wainwright et al., 2011; Bracken et al., 2013; Reaney et al., 2014; Okin et al., 2015). Surface patches respond to rainfall characteristics and (antecedent) soil moisture conditions to determine the initiation of runoff and thus, the transport of water and sediments through the landscape (Cantón et al., 2011; Mayor et al., 2011; RodríguezCaballero et al., 2014). Thus, functional connectivity may dynamically vary between rainfall events. There is little consensus, however, on how to quantify functional connectivity (Okin et al., 2015). Several research approaches were applied to analyse functional aspects of connectivity in terms of the continuity of runoff and sediment fluxes along hillslopes, landscapes and catchments. These approaches cover a wide array of methods including hierarchical (i.e. nested, stratified and/or scaled) runoff and sediment yield measurements (Cammeraat, 2004; Yair and Raz-Yassif, 2004; Moreno-delas-Heras et al., 2010; Mayor et al., 2011), field-based mapping and modelling of active runoff and sediment flow paths (Arnau-Rosalén et al., 2008; Marchamalo et al., 2016; Turnbull and Wainwrigth, 2019), fallout radionuclide and rareearth-element sediment tracing applications (Masselink et al., 2017a; Moreno-de-las-Heras et al., 2018), or particle-inmotion tracers and overland flow sensors (Hardy et al., 2017; Masselink et al., 2017b).

Mediterranean dry reclaimed mining slope systems (hereafter RMSSs) are characterized by the local convergence of high storm erosivity, poorly developed soils, scarce vegetation cover and rough topography. These characteristics can lead to the genesis of important amounts of overland flow, promoting soil erosion processes, which typically lead to rill and gully development (Nicolau and Asensio, 2000; Nicolau, 2002; Moreno-de-las-Heras et al., 2009; Martín-Moreno et al., 2018). The analysis of runoff and sediment connectivity has a critical relevance for landscape management in these human-made, water-limited environments, where the functional components of runoff and sediment connectivity (e.g. the processes that initialize, maintain or interrupt the fluxes of water and sediments from the surface-patch to the broader hillslope scale) can shape on-site structural-connectivity factors (e.g. vegetation patterns, spatial distribution of rill networks and sedimentation areas) over long periods, conditioning the long-term eco-geomorphic stability of the reclaimed systems (Moreno-de-las-Heras et al., 2011a). In fact, withinslope spatial redistribution of runoff and sediment fluxes in these Mediterranean dry RMSSs feeds back into patch-scale hydrological behaviour by controlling the availability of water and soil resources for the long-term development of vegetation cover (Espigares et al., 2011; Moreno-de-las-Heras et al., 2011b; Merino-Martín et al., 2015). Furthermore, the magnitude and cross-scale transmission of runoff and sediments in these RMSSs largely determines their off-site ef- 
fects in the form of runoff and sediment conveyance to downstream channels and environments (Martín-Moreno et al., 2018).

In this study, we apply the concepts of structural and functional connectivity to analyse the factors that control the transference of water and sediments from the surface-patch to the hillslope scale in three Mediterranean dry RMSSs that differ in their vegetation organization and landform features (i.e. rill networks). Our assessment is based on the analysis of patch-to-hillslope runoff and sediment flow continuity of 21 active events monitored during 2007-2008 using a hierarchical (scaled) measurement approach (Merino-Martín et al., 2012a). Specifically, our analysis aims to determine how structural components of the three reclaimed slope systems (i.e. the spatial distribution of vegetation cover and micro-topography, including rill networks) dynamically interact with rainfall characteristics (i.e. storm depth, rainfall duration and intensity) and antecedent storm conditions to generate spatially continuous runoff and sediment fluxes.

\section{Materials and methods}

\subsection{Study area}

This work was carried out in the Utrillas field site (Fig. 1a), an experimental station located in "El Moral", a reclaimed surface coal mine in central eastern Spain $\left(40^{\circ} 47^{\prime} 24^{\prime \prime} \mathrm{N}\right.$, $\left.0^{\circ} 49^{\prime} 48^{\prime \prime} \mathrm{W} ; 1100 \mathrm{~m}\right)$. The climate is Mediterranean dry, with a mean annual air temperature of $11^{\circ} \mathrm{C}$. Mean annual precipitation (MAP) is about $500 \mathrm{~mm}$, most of which occurs in spring and autumn. Potential evapotranspiration (PET; Hargreaves and Samani, 1985) is around $900 \mathrm{~mm}$, and the hydrological deficit (MAP-PET) is approx. $400 \mathrm{~mm}$, concentrated in the summer months (López-Martín et al., 2007). The average number of precipitation events in the area is 50-70 per year. Remarkable is the rainfall erosivity of high-intensity late-spring and summer convective thunderstorms $(<10 \%$ rainfall events), which can reach up to $100 \mathrm{~mm}$ rainfall in 24 h (Peña et al., 2002).

The study site encompasses three experimental slopes, all north facing with a general gradient of about $20^{\circ}$ (Fig. 1b and d), which were surveyed intensively between October 2007 and December 2008 (Merino-Martín et al., 2012a, 2015). The slopes were reclaimed during 1987-1989 with the following procedure. First, a $100 \mathrm{~cm}$ thick layer of clayloam overburden substratum was spread over the slopes. Next, the surface was prepared for revegetation by applying cross-slope ploughing to create a transversal pattern of surface roughness that would facilitate water storage and infiltration. Finally, the slopes were sown with a seed mixture of perennial grasses and leguminous herbs (Festuca rubra, Festuca arundinacea, Poa pratensis, Lolium perenne, Medicago sativa and Onobrychis viciifolia).
Although the three slopes were originally restored using the same procedure, their subsequent evolution and ecosystem recovery level displayed differences due to variations in their geomorphological design, particularly in the upper section of the slopes. Specifically, these variations occurred due to the existence of a very steep $\left(40^{\circ}\right)$ and bare runoffcontributing berm integrated at the top of two of the experimental slopes (Slope 1 and Slope 2, with berm sizes of 50 and $20 \mathrm{~m}^{2}$, respectively; Fig. 1b). This runoff-contributing structure promoted soil erosion and conditioned the early dynamics of the experimental slopes, particularly in Slope 1, where the berm area is bigger and produces important amounts of overland flow. These mechanisms resulted in the formation of a deeply incised (up to $35 \mathrm{~cm}$ depth in the middle and lower sections of the slope) and fairly dense $\left(0.6 \mathrm{~m} \mathrm{~m}^{-2}\right.$ density) rill network in Slope 1 and, also, important variations in vegetation development among the three experimental slopes. After 20 years of dynamic evolution from initial reclamation, the three experimental slopes showed different levels of vegetation development $(30 \%, 45 \%$ and $55 \%$ cover for Slope 1, Slope 2 and Slope 3, respectively), soil erosion intensity (2007-2008 sediment yield was 1824, 81 and $4 \mathrm{~g} \mathrm{~m}^{-2}$ for Slope 1, Slope 2 and Slope 3, respectively) and runoff production (2007-2008 runoff coefficient was $14.5 \%$, $2.1 \%$ and $0.4 \%$ for Slope 1, Slope 2 and Slope 3, respectively; Table S1 in the Supplement).

\subsection{Field acquisition methods of hydro-sedimentary and precipitation data}

We monitored runoff and soil erosion in the experimental slopes by applying a scaled approach (Merino-Martín et al., 2012a) that included naturally delimited runoff and erosion plots distributed at (a) the hillslope scale and (b) the surfacepatch scale (Fig. 1c).

Three broad, hillslope-scale runoff and erosion plots were installed in naturally delimited catchments in the experimental slopes (catchment areas of 498, 511 and $1474 \mathrm{~m}^{2}$ for Slope 1, Slope 2 and Slope 3, respectively; Fig. 1d). At the foot of each catchment, two collectors and a central cemented outlet were installed. From the outlet, runoff was routed through a pipe into $200 \mathrm{~L}$ storage tanks connected by Geib (1933) multi-slot runoff dividers (Fig. 1d).

At the patch scale, seven different soil surface types were identified within the experimental slopes as a function of vegetation community composition and soil surface traits (e.g. dominant plant species, species richness, cover, presence of soil surface crusts and small pedestals). The soil surfacepatch types (Fig. 1e; Table S1) included barely covered areas $(<5 \%$ cover) with scattered clumps of perennial forbs dominated by Medicago sativa (Ms); sparsely covered areas (cover approx. $30 \%$ ) with grasses dominated by Dactylis glomerata (Dg) or with dwarf shrubs dominated by either Santolina chamaecyparissus (Sch) or Thymus vulgaris (Tv); and finally, densely covered areas ( $>70 \%$ cover) dominated 
(a)

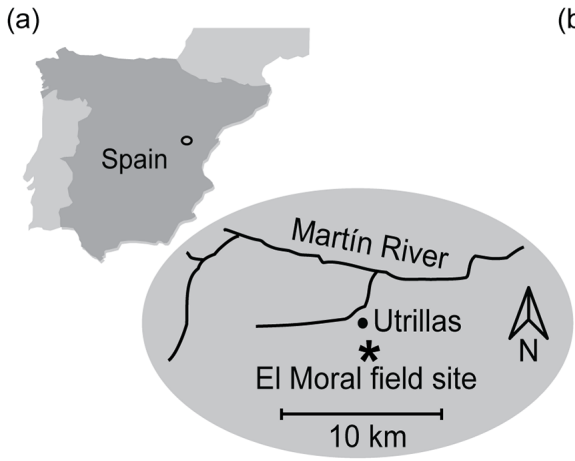

(b)

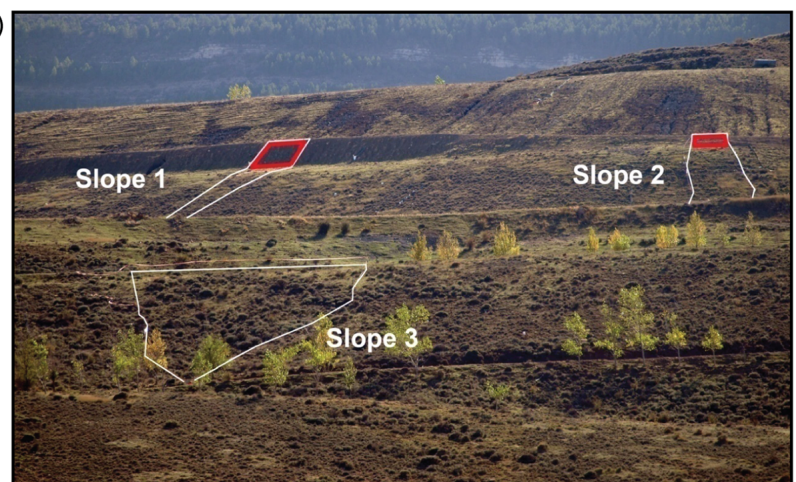

(c)

(d)

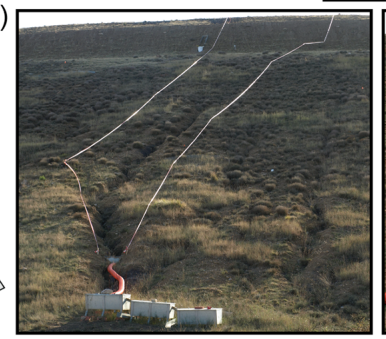

Slope 1 (S1) Vegetation cover: $30 \%$ Rill density: $0.6 \mathrm{~m} \mathrm{~m}^{-2}$

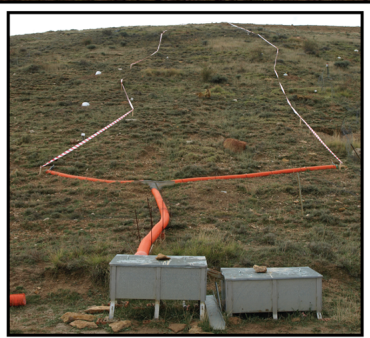

Slope 2 (S2) Vegetation cover: $45 \%$ Rill density: $0.0 \mathrm{~m} \mathrm{~m}^{-2}$

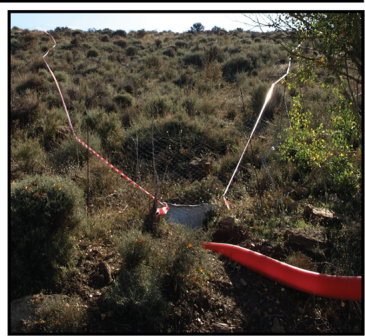

Slope $3(\mathrm{~S} 3)$

Vegetation cover: $55 \%$ Rill density: $0.0 \mathrm{~m} \mathrm{~m}^{-2}$

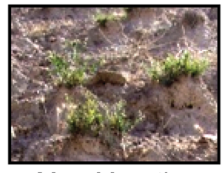

Ms - M. sativa (Slopes S1, S2)

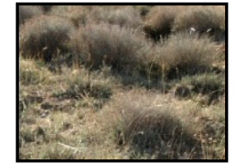

Sch - S. chamaecyp. (Slopes S1, S2, S3)

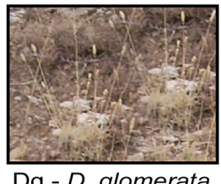

Dg - D. glomerata (Slope S2)
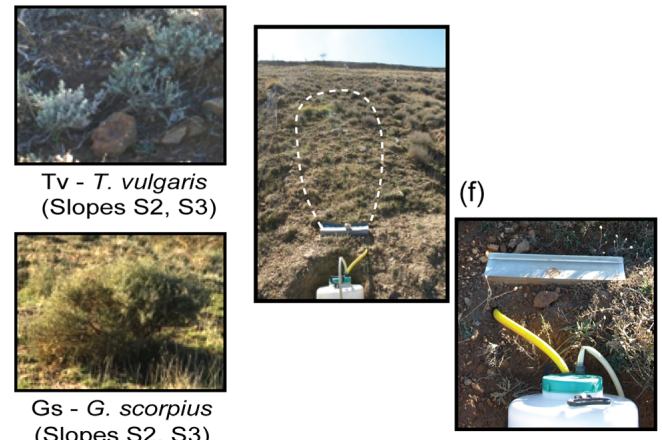

Figure 1. The Utrillas field site: (a) location map; (b) frontal view of the three experimental slopes $\left(40^{\circ}\right.$ steep, berm sections located at the top of Slope 1 and Slope 2 are highlighted in red); (c) schematic representation of the experimental layout in the slopes (a hierarchical, scaled approach with patch-scale and hillslope-scale runoff and erosion plots); (d) frontal view of the hillslope-scale plots (catchment plots) and their general characteristics (vegetation cover and rill density); (e) detailed view of the seven surface types (vegetation communities) identified in the experimental slopes by Merino-Martín et al. (2012a); (f) an example of patch-size plot showing a small detail (right picture) of the Gerlach trough runoff and sediment collection systems. Names of the dominant plant species for the surface types: Ms, Medicago sativa; Sch, Santolina chamaecyparissus; Dg, Dactylis glomerata; Tv, Thymus vulgaris; Lp, Lolium perenne; Br, Brachypodium retusum; and Gs, Genista scorpius.

by grass species (Lolium perenne, Lp, and Brachypodium retusum, Br) or by shrubs (Genista Scorpius, Gs). In order to monitor runoff and sediment yield at the patch scale, 27 Gerlach (1967) troughs (each $0.5 \mathrm{~m}$ wide and connected to $100 \mathrm{~L}$ drums for runoff and sediment storage; Fig. 1f) were distributed in the slopes between the seven surface types. The spatial organization of the surface types and contributing area of the Gerlach troughs in the experimental slopes was determined in the field using a total station (Topcon GTS212). The catchment area of the Gerlach troughs, delimitated by surface micro-topography and vegetation barriers, ranged from 1 to $16 \mathrm{~m}^{2}$ (Table S1).

The runoff amount was measured in the storage tanks and drums within a day after each runoff event (runoff-producing events occurring within a $24 \mathrm{~h}$ period were considered to belong to the same event). The stored runoff was stirred, and $1 \mathrm{~L}$ representative samples were taken. Sediment concentrations were determined by oven-drying the collected runoff samples (at $105^{\circ} \mathrm{C}$ ) until a constant weight was achieved.

A set of six precipitation variables (Table 1) were measured for each of the monitored events. The rain- 
Table 1. Precipitation condition variables determined for each monitored runoff event.

\begin{tabular}{lll}
\hline & Description & Units \\
\hline Dp & Storm depth & $\mathrm{mm}$ \\
Rd & Rainfall duration & $\mathrm{h}$ \\
$I_{15}$ & 15 min max rainfall intensity & $\mathrm{mm} \mathrm{h}^{-1}$ \\
$I_{30}$ & 30 min max rainfall intensity & $\mathrm{mm} \mathrm{h}^{-1}$ \\
$I_{\mathrm{m}}$ & Mean rainfall intensity & $\mathrm{mm} \mathrm{h}^{-1}$ \\
API & Antecedent precipitation index & $\mathrm{mm}$ \\
\hline
\end{tabular}

fall depth (Dp, mm) for each event was measured using three bulk precipitation collectors located within the experimental slopes. Rainfall duration $(\mathrm{Rd}, \mathrm{h})$ and both 15 and 30 min maximum rainfall intensities $\left(I_{15}\right.$ and $I_{30}$, respectively, $\mathrm{mm} \mathrm{h}^{-1}$ ) were measured using an automated recording rain gauge (Davis GroWeather) installed in the experimental station. The mean rainfall intensity $\left(I_{\mathrm{m}}, \mathrm{mm} \mathrm{h}^{-1}\right)$ for each event was calculated as the ratio of total precipitation to rainfall duration. In order to characterize the antecedent rainfall conditions of the events, we used the antecedent precipitation index (API, mm; Kohler and Linsley, 1951). API is calculated as

$\mathrm{API}=\sum_{t=-1}^{-T} P_{t} k^{-t}$,

where $P_{t}(\mathrm{~mm})$ is the precipitation on a given day $t, k$ is a dimensionless decay coefficient that represents a measure of the declining influence of past precipitation on current soil moisture state and $T$ (d) is the antecedent period considered for the calculation of the index. We used fortnightly soil moisture records obtained in the experimental slopes $(3 \times 12$ TDR - time domain reflectometry - profiles of $50 \mathrm{~cm}$ depth; Merino-Martín et al., 2015) to parameterize API for this study $(k=0.98$ and $T=10 \mathrm{~d}$; complementary field-calibration details of API parameters in Sect. S1 in the Supplement).

A total of 21 rainfall events out of 74 precipitations produced runoff and erosion at the patch scale during the study period (October 2007-December 2008; total rainfall of $703 \mathrm{~mm}$ ), although only 17 generated significant hydrological responses at the hillslope scale (Merino-Martin et al., 2012a). We used the complete set of 21 hydrologically active events for this study (full hydro-sedimentary and precipitation data are available in Table S2).

\subsection{Structural-connectivity quantification: distribution of sources and sinks}

Previous research carried out in the Utrillas field site applying small-scale $\left(0.25 \mathrm{~m}^{2}\right)$ rainfall simulations (Moreno-delas-Heras et al., 2009) indicated that surface patches with vegetation cover under $50 \%$ can generate important amounts of runoff and sediments, thus acting as "sources" of water runoff and sediments within the slopes. Conversely, surface patches with vegetation cover above $50 \%$ regulate soil surface hydrological responses very efficiently and may also operate as flow obstructions, behaving as "sinks" of runoff and sediments. Structural connectivity for this study (i.e. the physical linkage of runoff and sediment source areas within the experimental slopes) has been quantified from coupled analysis of binary maps of vegetation density (above or below $50 \%$ cover) derived from high-resolution multispectral aerial photography and field-based digital elevation models (DEMs) of the experimental slopes.

Multispectral information of the experimental slopes was obtained from a high-resolution four-band aerial image ( $0.5 \mathrm{~m}$ resolution) captured by the Spanish National Plan for Aerial Orthophotography (PNOA, Spanish National Geographic Institute) in late spring 2009. We used the red and near-infrared bands to generate raster maps of the normalized difference vegetation index (NDVI). The NDVI is a chlorophyll-sensitive vegetation index that strongly correlates with vegetation cover and green biomass density (Anderson et al., 1993). We applied field-based NDVI thresholding (Scanlon et al., 2007) to transform the raster NDVI maps of the experimental slopes into binary maps of sinks and sources of runoff and sediments. First, we used reference vegetation density data collected in the field $(3 \times 35$ quadrats of $0.25 \mathrm{~m}^{2}$ size regularly distributed within the experimental slopes; Merino-Martín et al., 2012b) for determining the proportional abundance of sink areas with above $50 \%$ vegetation cover for each analysed slope system. We then classified the pixels in each slope by thresholding the NDVI values in the raster maps to match the ground-based proportional abundance of sink areas obtained in the first step. The application of this image processing methodology resulted in the generation of a high-resolution binary map product representing the distribution of sinks and sources $(>50 \%$ and $<50 \%$ cover patches, respectively) of runoff and sediments for each experimental slope.

Detailed digital elevation data for the analysis of structural connectivity were obtained from a topographical field survey (Merino-Martín et al., 2015). DEM break lines and filling points ( $\sim 0.5$ points $\mathrm{m}^{-2}$ data density) were obtained using a total station (Topcon GTS212). Scattered elevation data were interpolated using thin-plate splines to match the $(0.5 \mathrm{~m}$ resolution) grid-based binary maps of sources and sinks of the experimental slopes.

We used the flow length calculator developed by Mayor et al. (2008) along with the source and sink binary maps and the obtained DEM data to analyse the physical linkage of runoff and sediment source areas in the experimental slopes (Fig. 2a). This calculator applies a D8 flow-routing algorithm (O'Callaghan and Mark, 1984) to determine the length of the runoff paths in the downslope direction (flow length, Fl, m) until a sink (i.e. $>50 \%$ vegetation cover) or the outlet of the hillslope is reached. Flow path measurements were standard- 
ized to obtain a structural-connectivity indicator (SC, dimensionless). Standardization was carried out for every pixel in the raster maps of the experimental slopes by determining the ratio of the calculated $\mathrm{Fl}$ values to the topography-based flow path distance $(D, \mathrm{~m})$ of the pixels to the outlet of the hillslopes $\left(\mathrm{SC}_{i}=\mathrm{Fl}_{i} / D_{i}\right.$; Fig. 2a). $\mathrm{SC}$ values range from 0 (sink pixels) to 1 (source pixels connected to the outlet of the slope system without the interference of any sinks).

\subsection{Functional-connectivity quantification: flow continuity across scales}

Functional connectivity for this study is defined as the continuity of runoff and sediment fluxes from the surface-patch to the hillslope scales. We applied a two-step approach to determine functional connectivity (Fig. 2b). First, for each event and experimental slope, we determined the integrated patch-scale response of runoff and sediment yield $\left(R_{\mathrm{IPS}}, \mathrm{mm}\right.$, and $S_{\text {IPS }}, \mathrm{g} \mathrm{m}^{-2}$, respectively). This integrated patch-scale response was computed by weighing the surface-patch runoff and sediment observations (from the data recorded in the Gerlach troughs) with the proportional area of the different soil surface types monitored in each slope system. Second, functional connectivity, assessed as the cross-scale flow continuity of runoff and sediment fluxes $\left(C_{\mathrm{R}}\right.$ and $C_{\mathrm{S}}$, respectively), was quantified for each event and experimental slope as the ratio of the hydrological and sediment observations recorded in the broad, hillslope-scale plots $\left(R_{\mathrm{HS}}\right.$, $\mathrm{mm}$, and $S_{\mathrm{HS}}, \mathrm{g} \mathrm{m}^{-2}$, respectively) to the determined, integrated patch-scale responses of runoff and sediment yield $\left(C_{\mathrm{R}}=R_{\mathrm{HS}} / R_{\mathrm{IPS}}\right.$ and $C_{\mathrm{S}}=S_{\mathrm{HS}} / S_{\mathrm{IPS}} ;$ Fig. $\left.2 \mathrm{~b}\right)$.

The functional connectivity of runoff $\left(C_{R}\right.$, dimensionless) ranges between 0 and $1 . C_{\mathrm{R}}$ equals 0 when there is complete within-slope spatial redistribution of runoff (i.e. no runoff generated at the surface-patch scale reaches the outlet of the slope system). $C_{\mathrm{R}}$ increases as runoff redistribution decreases across scales and equals 1 when all runoff generated at the patch scale reaches the outlet of the slope system. Previous research in our study site suggests that any further contributions to hillslope runoff production (e.g. subsurface return fluxes captured by the rill networks) have a marginal impact on the hydrological response of these water-limited systems (Nicolau, 2002; Moreno-de-las-Heras et al., 2010; Merino-Martín et al., 2012a).

The functional connectivity of sediments $\left(C_{\mathrm{S}}\right.$, dimensionless) decreases from 1 to 0 when significant amounts of sediments generated at the patch scale are deposited within the slope system before reaching the outlet. However, $C_{\mathrm{S}}$ may take values over 1 if active rill incision takes place in the experimental slopes, causing the entrainment of significant amounts of sediments between the patch and hillslope scales (Moreno-de-las-Heras et al., 2010).

\subsection{Data analysis and statistics}

\subsubsection{General patterns of structural and functional connectivity}

For each experimental slope, we calculated the cumulative probability distribution function (CDF) of the structuralconnectivity (SC) values. Differences between the three experimental slopes on the SC probability distribution (probability of $\mathrm{SC}_{i} \geq \mathrm{SC}$ ) were analysed using two-sample Kolmogorov-Smirnov tests. Mean SC values (hereafter $\overline{\mathrm{SC}}$ ) were calculated for each slope system as an integrative indicator of the structural connectivity at the hillslope-scale level.

Differences between the three experimental slopes on the functional connectivity of runoff $\left(C_{\mathrm{R}}\right)$ and sediments $\left(C_{\mathrm{S}}\right)$ were tested for the set of 21 hydrologically active events recorded during the study period using Kruskal-Wallis ANOVA. In addition, the broad, hillslope-scale hydrological (sediment) responses of the experimental slopes were tested against the analysed, per-event functional connectivity of the studied systems by determining the best-fitting regression function linking the determined runoff (sediment) connectivity values and the observed hillslope runoff coefficients (soil losses).

\subsubsection{Controlling factors of runoff and sediment connectivity}

We applied the general descriptors of precipitation characteristics and antecedent rainfall conditions (Table 1) and the obtained $\overline{\mathrm{SC}}$ index of structural connectivity to determine the main controlling factors that drive the functional responses of runoff and sediment connectivity in the experimental slopes for the studied ( 21 hydrologically active) runoff and erosion events. We modelled $C_{\mathrm{R}}$ and $C_{\mathrm{S}}$ using general linear models (GLMs; Christensen, 2002) and a backward model structure selection approach. First, an exploratory pre-screening analysis of the dynamic relationships between the functionalconnectivity indexes $\left(C_{\mathrm{R}}\right.$ and $\left.C_{\mathrm{S}}\right)$ and both the rainfall characteristics and antecedent precipitation conditions was performed using Spearman's $R$ correlations. Second, the prescreened variables that showed significant correlations (at $\alpha=0.05$ ) with the $C_{\mathrm{R}}$ and $C_{\mathrm{S}}$ values of the storms were further applied to model the surface-patch to hillslope transfer (or flow continuity) of runoff and sediments.

In order to identify the set of explanatory variables that produce the best model for $C_{\mathrm{R}}$ and $C_{\mathrm{S}}$ prediction, alternative GLM configurations were compared. These alternative GLM configurations included (i) $\overline{\mathrm{SC}}$ as a factor with three levels representing the structural connectivity of the three experimental slopes, (ii) all the possible combinations of significant (Spearman's $R$ ) pre-screened variables of rainfall characteristics and antecedent conditions, and (iii) the interaction terms between $\overline{\mathrm{SC}}$ and the pre-screened variables included in each comparison of model structure. The Akaike information 
(a)

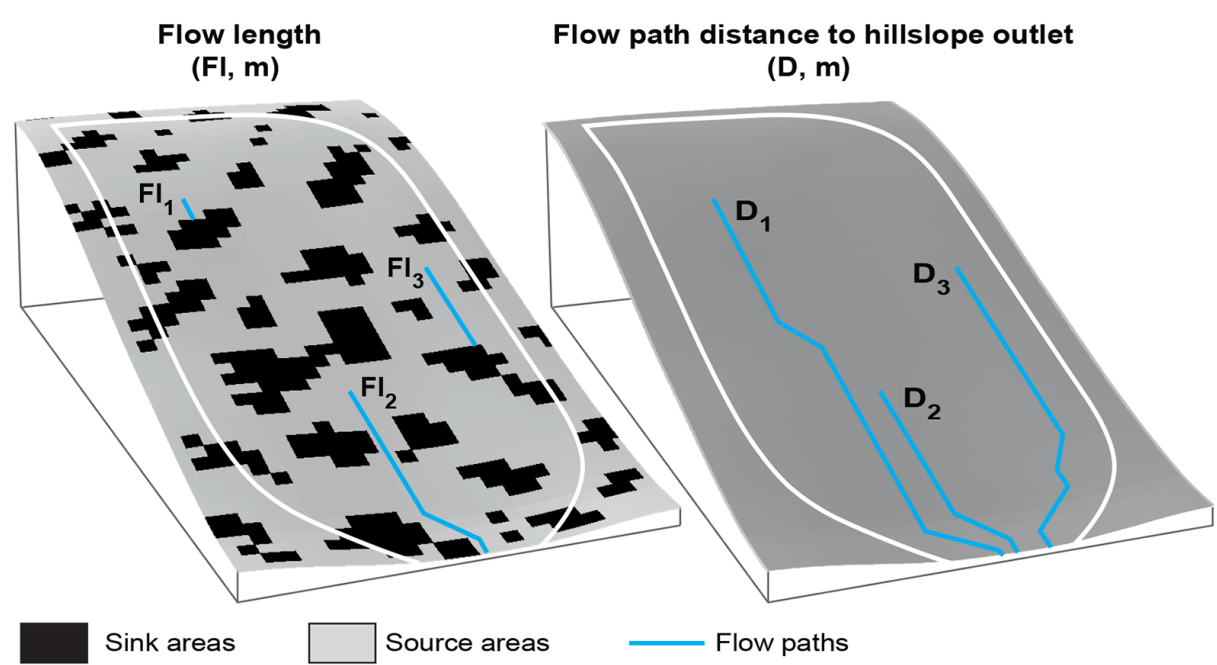

Structural-connectivity calculations

Stuctural connectivity (SC, dimensionless)

$$
\mathrm{SC}_{\mathrm{i}}=\mathrm{FI}_{\mathrm{i}} / \mathrm{D}_{\mathrm{i}}
$$

\section{Virtual example}

$$
\mathrm{FI}_{1}=3 \mathrm{~m} ; \mathrm{D}_{1}=59 \mathrm{~m}
$$

$\mathrm{FI}_{2}=24 \mathrm{~m} ; \mathrm{D}_{2}=24 \mathrm{~m}$

$\mathrm{FI}_{3}=11 \mathrm{~m} ; \mathrm{D}_{3}=36 \mathrm{~m}$

$$
\begin{aligned}
& \mathrm{SC}_{1}=0.05 \\
& \mathrm{SC}_{2}=1.00 \\
& \mathrm{SC}_{3}=0.31
\end{aligned}
$$

(b)

Functional-connectivity calculations

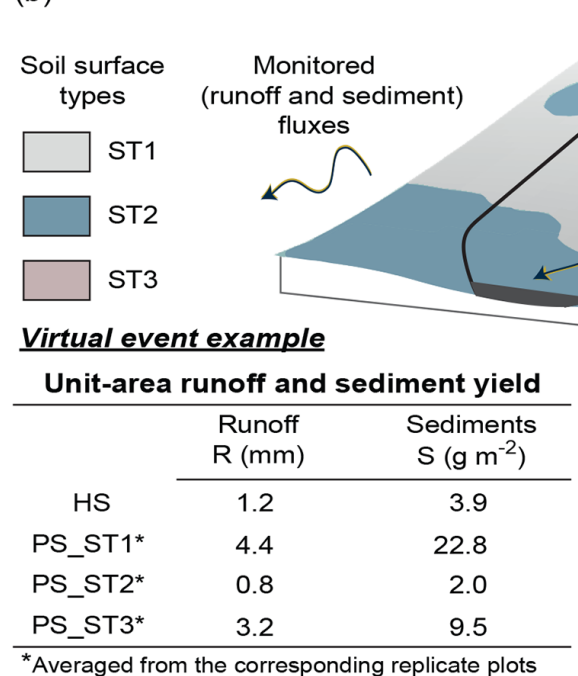

Proportional area of surface types in HS

\begin{tabular}{llll}
\hline & ST1 & ST2 & ST3 \\
\cline { 2 - 4 } $\mathrm{A}$ & 0.60 & 0.20 & 0.20 \\
\hline
\end{tabular}

$$
\begin{aligned}
& \text { Integrated patch-scale response } \\
& \text { of runoff }\left(\mathbf{R}_{\mathrm{IPS}}, \mathbf{m m}\right) \\
& \qquad \mathrm{R}_{\mathrm{IPS}}=\sum_{i=1}^{n}\left(R_{\mathrm{PS} S \mathrm{STi}}{ }^{*} A_{\mathrm{STi}}\right) \\
& \qquad \mathrm{R}_{\mathrm{IPS}}=3.44 \mathrm{~mm}
\end{aligned}
$$

of sediment yield $\left(S_{\text {IPS }}, \mathrm{g} \mathrm{m}^{-2}\right)$

$$
\begin{gathered}
S_{I P S}=\sum_{i=1}^{n}\left(S_{P S \_S T i}{ }^{*} A_{S T i}\right) \\
S_{I P S}=15.98 \mathrm{~g} \mathrm{~m}^{-2}
\end{gathered}
$$

Functional connectivity of runoff $\left(C_{R}\right.$, dimensionless)

$$
\begin{gathered}
C_{R}=R_{H S} / R_{I P S} \\
C_{R}=0.35
\end{gathered}
$$

of sediments $\left(C_{S}\right.$, dimensionless)

$$
\begin{gathered}
C_{S}=S_{H S} / S_{I P S} \\
C_{S}=0.24
\end{gathered}
$$

Figure 2. Schematic representation and virtual examples of the calculations for the quantification of (a) structural connectivity (SC) and (b) the functional connectivity of both runoff $\left(C_{\mathrm{R}}\right)$ and sediments $\left(C_{\mathrm{S}}\right)$. Structural connectivity for any location in the hillslope $\left(\mathrm{SC}_{i}\right)$ is calculated as the ratio of flow length $\left(\mathrm{Fl}_{i}\right.$, length of the runoff path until a sink is reached downslope of the hillslope location) to the (topography-based) flow path distance of the location to the hillslope outlet $\left(D_{i}\right)$. For each precipitation event, functional connectivity of runoff, $C_{\mathrm{R}}$ (of sediments, $C_{\mathrm{S}}$ ), is calculated as the ratio of hillslope-scale runoff, $R_{\mathrm{HS}}$ (sediment yield, $S_{\mathrm{HS}}$ ), to the integrated (i.e. areaweighed) patch-scale production of runoff, $R_{\text {IPS }}$ (of sediments, $S_{\text {IPS }}$ ). The virtual slope in $(\mathbf{b})$ includes three replicate PS_ST patch-scale plots for each of the three displayed STi soil surface types.

criterion (AIC; Akaike, 1974) and the adjusted coefficient of determination (Adj $R^{2}$ ), which represent a trade-off between model complexity and the goodness of fit, were used to select the best model for $C_{\mathrm{R}}$ and $C_{\mathrm{S}}$ prediction. Finally, the model root-mean-squared error (RMSE) and both the effect size (eta-squared values, $\eta^{2}$ ) and significance of the model predictors were evaluated for the selected, optimal GLM config- urations. While $C_{\mathrm{S}}$ may take values (largely) above 1 when active rilling takes place, $C_{\mathrm{R}}$ is constrained to values $\leq 1$ and consequently, may asymptotically approach 1 as rainfall increases. The asymptotic behaviour of $C_{\mathrm{R}}$ violates the GLM assumption of linearity for large values of the model predictors. We, therefore, applied logarithmic transformation to the 
precipitation co-variables (Table 1) to comply with the GLM assumptions for $C_{\mathrm{R}}$ modelling.

All data analyses and statistics were developed within the $\mathrm{R}$ statistical computing and language programming software environment (R Core Team, 2019).

\section{Results}

\subsection{Source and sink distribution and structural connectivity of the slopes}

Runoff and sediment sinks in Slope 1 were particularly concentrated in its central section, mainly distributed as grass patches dominated by Lolium perenne (Lp soil surface-patch type; Fig. 3a). A well-developed rill network (density of $0.6 \mathrm{~m} \mathrm{~m}^{-2}$ ) linked the runoff and sediment source areas located at the top of the experimental slope with both the source areas distributed at the bottom of the slope and the outlet of the system. Similarly, runoff and sediment sink areas for Slope 2 (Fig. 3b) were preferentially distributed in the central part of the slope system, mostly in the form of densely vegetated grass and shrub patches (surface-patch types Lp, Br, Dg and Gs). However, runoff and sediment source areas at the top of Slope 2 were not connected with the source areas distributed at the bottom of this experimental slope. Finally, sink areas for Slope 3 were broadly distributed in the form of densely vegetated shrub clumps (Gs and Sch surface-patch types) within the central and lower sections of the slope system (Fig. 3c), largely hindering the connectivity between the source areas distributed at the top of the slope and the outlet of the system.

Figure $3 d$ shows the cumulative probability distribution function of the structural-connectivity metric (SC CDF) in the three experimental slopes, along with their mean hillslope values $(\overline{\mathrm{SC}})$. Two-sample Kolmogorov-Smirnov tests indicated that the SC CDFs significantly differed between the three experimental slopes at $\alpha=0.01$. For the rilled system (Slope 1), the probability of finding runoff and sediment source areas physically linked to the outlet of the slope system (probability of $\mathrm{SC}_{i}=1$ ) was $42 \%$, leading to a large mean structural connectivity at the hillslope level $(\overline{\mathrm{SC}}=0.47)$. Conversely, the abundance of barely covered, source areas connected with the outlets of the two non-rilledslope systems (Slope 2 and Slope 3) was substantially lower (probability of $\mathrm{SC}_{i}=1$ is $12 \%$ and $<1 \%$ for Slope 2 and Slope 3, respectively). Furthermore, the large spatial dominance of sink patches in the middle and bottom section of Slope $3(\overline{\mathrm{SC}}=0.02)$ very considerably reduced the structural connectivity of this hillslope as compared to Slope 2 $(\overline{\mathrm{SC}}=0.17)$, where the bottom section of the hillslope is dominated by source patches.

\subsection{Functional connectivity: cross-scale continuity of runoff and sediments}

Functional connectivity of runoff across scales showed important differences for the three experimental slopes. Cumulative runoff production along the study period (2007-2008) decreased from the surface-patch scale to the hillslope scale for all the three experimental slopes (Fig. 4a). However, these variations in runoff production across scales showed remarkable differences between the slopes. For the rilled system (Slope 1), the cross-scale connectivity of 2007-2008 cumulative runoff was 0.72 , indicating that $72 \%$ of the runoff that was generated at the patch-scale level during the study period effectively reached the outlet of the system (in other words, $28 \%$ runoff was redistributed or re-infiltrated within the slope during 2007-2008). In contrast, less than $20 \%$ of the patch-scale runoff reached the outlets of the non-rilled systems (i.e. connectivity of cumulative runoff was 0.17 and 0.06 for Slope 2 and Slope 3, respectively; Fig. 4a).

Runoff connectivity displayed an important variability among the various monitored events $\left(C_{\mathrm{R}}\right.$; Fig. $\left.4 \mathrm{c}\right)$. The values of runoff connectivity across scales in Slope 1 ranged from 0 to around 1 for the 21 active events. In particular rainfall events, there was complete runoff redistribution within this slope (i.e. $C_{\mathrm{R}}=0$ ), while in other events all runoff generated at the patch-scale level reached the outlet of the system (i.e. $C_{\mathrm{R}}$ about 1). In the case of Slope 2 and Slope 3, the maximum and mean values of runoff connectivity were notably smaller than for Slope 1, indicating that for all the events, larger fractions of patch-scale runoff were spatially redistributed (i.e. downslope re-infiltrated) within the two nonrilled systems

Functional connectivity of cumulative (2007-2008) sediment yields also showed important differences among the experimental slopes (Fig. 4b). For the rilled system (Slope 1), the cumulative sediment yield at the hillslope scale was 1.6 times larger than patch-scale sediment production. Conversely, the continuity of sediment fluxes across scales was very low for the non-rilled slopes: less than $15 \%$ of the cumulative sediments generated at the patch-scale level in Slope 2 and Slope 3 during the study period reached the outlet of these non-rilled systems.

At the rainfall-event level, the cross-scale continuity of sediment fluxes showed a large variability $\left(C_{S}\right.$; Fig. $\left.4 d\right)$. This effect was especially important for the rilled system (Slope 1), where there was complete spatial redistribution of sediments for particular events (i.e. $C_{S}=0$ ), while for other events in this slope, the hillslope-scale sediment yield was up to 5 times larger than patch-scale sediment production. The flow continuity of sediments across scales for the nonrilled-slope systems (Slope 2 and Slope 3) was low for all the recorded events (maximum sediment connectivity was 0.4 and 0.07 for Slope 2 and Slope 3, respectively), showing substantial sediment deposition from the patch to the hillslope scales. 
(a) Slope 1 (S1)

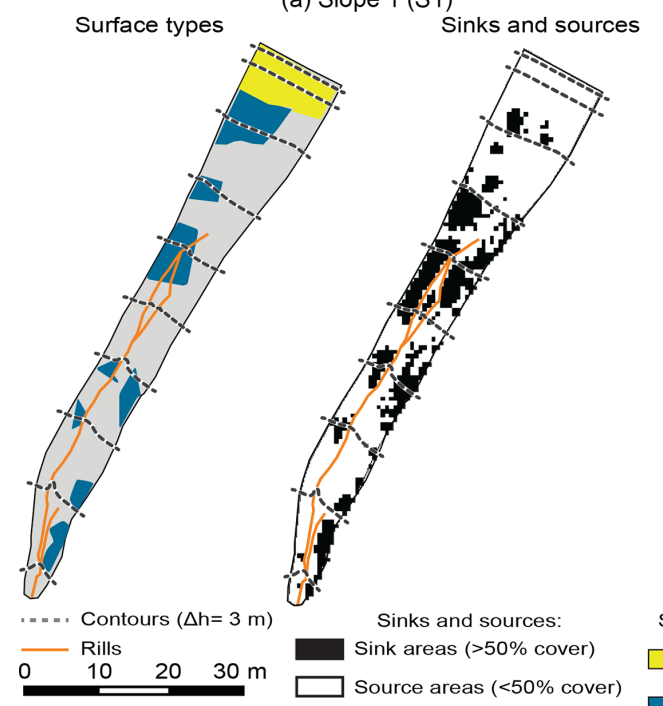

(c) Slope 3 (S3)
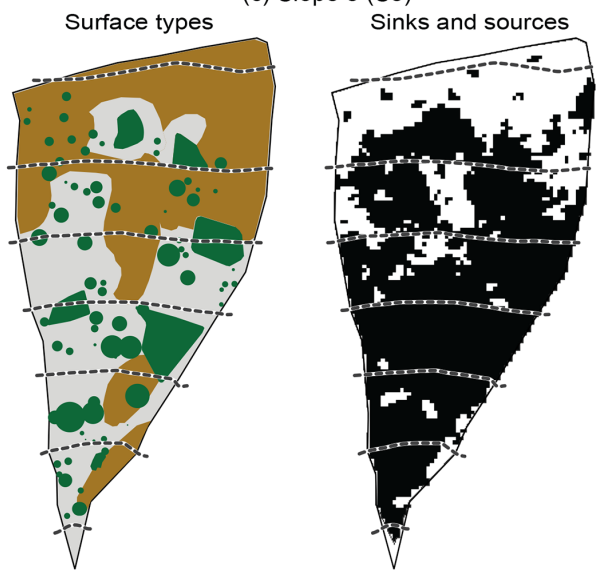

(b) Slope 2 (S2)

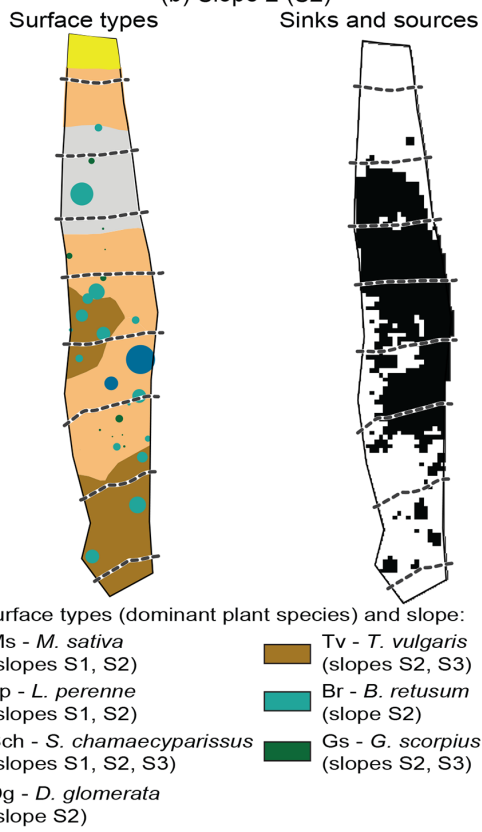

(d) Probablity distribution of the structural connectivity (SC) of source areas

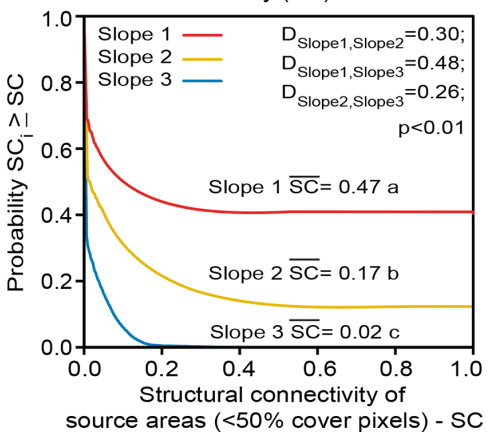

Figure 3. Structural connectivity: (a-c) spatial organization of surface types (vegetation communities) and sink and source areas (i.e. areas above or below $50 \%$ vegetation cover) in the experimental slopes; (d) cumulative probability distribution function (CDF) of the structuralconnectivity (SC) metric of source areas for the experimental slopes (mean structural-connectivity values, $\overline{\mathrm{SC}}$, are provided for each slope system). Surface type maps and digital elevation data were derived from a topographical field survey (Merino-Martín et al., 2015). Binary maps (0.5 m pixel resolution) of sinks and sources are derived from a multispectral aerial picture (Spanish National Plan for Aerial Orthophotography, PNOA). Different letters in $\overline{\mathrm{SC}}$ values displayed in the graph in panel (d) indicate significant differences at $\alpha=0.01$. Tested using two-sample Kolmogorov-Smirnov tests ( $D$ statistics and $p$ levels are shown in the graph).

The per-event hillslope runoff coefficient and soil erosion increased non-linearly with increasing runoff $\left(C_{\mathrm{R}}\right)$ and sediment $\left(C_{\mathrm{S}}\right)$ connectivity, respectively. The hillslope runoff production showed slight variations with cross-scale runoff connectivity up to $C_{\mathrm{R}}$ values of about 0.5 (50\% runoff redistribution between the patch and hillslope scales) over which the runoff coefficients of the experimental slopes increased very rapidly (from $\sim 5 \%$ to about $30 \%$; Fig. 4 e). Similarly, hillslope soil erosion showed little change with $C_{\mathrm{S}}<1$, when active within-slope sediment deposition took place (Fig. 4f). However, for $C_{\mathrm{S}}$ values above 1 , when the rill networks actively contributed with fresh sediments to the flow, broad hillslope-scale soil erosion increased very strongly, up to
2 orders of magnitude. These very high $C_{\mathrm{S}}$ values, observed during extreme sediment response events ( $C_{\mathrm{S}}$ peaking up to nearly 5; Fig. 4d and f), suggest that erosion from the rill networks can contribute with up to 4 times more sediments to the outlet than the poorly covered (source) surface patches acting in the experimental slopes.

\subsection{Impact of structural and dynamic factors on runoff and sediment connectivity}

Exploratory analysis of the relationship between runoff connectivity $\left(C_{\mathrm{R}}\right)$ and the event characteristics indicated that antecedent precipitation (API), both maximum $\left(I_{15}\right.$ and $\left.I_{30}\right)$ 

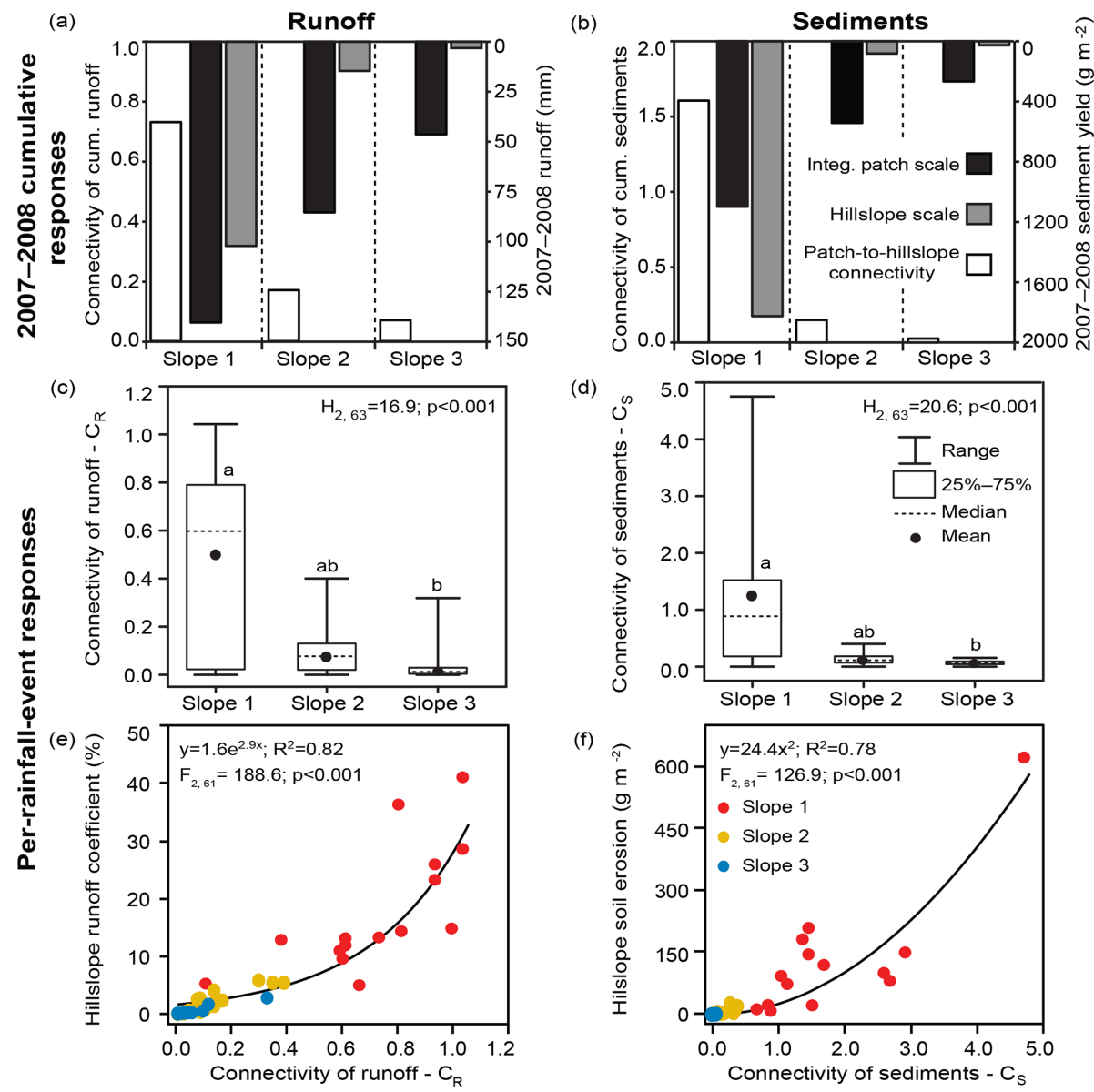

Figure 4. Functional connectivity: (a, b) 2007-2008 cumulative and (c, d) per-rainfall-event connectivity of $(\mathbf{a}, \mathbf{c})$ runoff $\left(C_{\mathrm{R}}\right)$ and $(\mathbf{b}, \mathbf{d})$ sediments $\left(C_{\mathrm{S}}\right)$ in the experimental slopes; $(\mathbf{e}, \mathbf{f})$ relationship between the (per-rainfall-event) connectivity of runoff and sediments and the hillslope-scale runoff coefficient and soil erosion. Connectivity of runoff and sediments across scales is represented as the ratio of hillslopescale to patch-scale runoff and sediments (white bars). Runoff and sediment yield at both the hillslope scale (grey bars) and the integrated (i.e. area-weighed) patch scale (black bars) are provided for the 2007-2008 cumulative metrics (secondary vertical axis of graphs in panels a and b). Different letters in bars of the graphs in panels (c) and (d) indicate significant differences for the three slopes at $\alpha=0.05$. Tested using Kruskal-Wallis ANOVA ( $H$ statistics and $p$ levels are shown in the graphs).

and mean $\left(I_{\mathrm{m}}\right)$ rainfall intensity, and storm depth $(\mathrm{Dp})$ significantly correlated with the continuity of runoff across scales (Table 2). These correlations were particularly strong for antecedent precipitation in all the analysed slope systems (0.75-0.80 for Spearman's $R$ ). GLM modelling of observed $C_{\mathrm{R}}$ values using the pool of significant event characteristics (API, $I_{15}, I_{30}, I_{\mathrm{m}}$ and Dp) pointed to the effects of (log-transformed) API and $I_{30}$ variables, hillslope structural connectivity $(\overline{\mathrm{SC}})$, and their corresponding interaction terms ( $\overline{\mathrm{SC}}: \mathrm{API}$ and $\left.\overline{\mathrm{SC}}: I_{30}\right)$ as the best model structure predictors $\left(R^{2}=0.81\right.$, Adj $R^{2}=0.78$ and normalized $\mathrm{RMSE}=12 \%$; Fig. 5a). No additional increments of GLM complexity resulted in significant improvements of explained $C_{\mathrm{R}}$ variance (Adj $R^{2}$ values of alternative models in Table S3). The $\eta^{2}$ values for the optimal $C_{\mathrm{R}}$ model $\left(\eta^{2}\right.$; Fig. 5a) revealed a primary influence of hillslope structural connectivity, which absorbed $44.1 \%$ and $16.8 \%$ of $C_{\mathrm{R}}$ variance in the form of direct $(\overline{\mathrm{SC}})$ and interaction $\left(\overline{\mathrm{SC}}\right.$ : API and $\left.\overline{\mathrm{SC}}: I_{30}\right)$ effects, respectively. The direct effects of the event-driven (API and $I_{30}$ ) variables accounted for an additional $20 \%$ of the observed $C_{\mathrm{R}}$ variance $\left(12.9 \%\right.$ and $7.1 \%$ for API and $I_{30}$, respectively).

An increase in both antecedent precipitation and $30 \mathrm{~min}$ maximum rainfall intensity led to non-linear increases in runoff connectivity for all the analysed slope systems (Fig. 5b and c). $C_{\mathrm{R}}$ increased rapidly for values within $0-20 \mathrm{~mm} \mathrm{~h}^{-1}$ of maximum rainfall intensity and $0-50 \mathrm{~mm}$ of antecedent precipitation, tending to saturate for larger $I_{30}$ and API values. However, the structural connectivity $(\overline{\mathrm{SC}})$ of the analysed slope systems exerted a strong control on these effects. Both maximum rainfall intensity and antecedent precipitation increased runoff connectivity very little for Slope 2 and Slope 3, as a result of the large within-slope redistribution of runoff that prevailed under all rainfall conditions 
(a) Best model $\mathrm{C}_{\mathrm{R}} \sim \mathrm{I}_{30}+\mathrm{API}+\overline{\mathrm{SC}}+\overline{\mathrm{SC}}: \mathrm{I}_{30}+\overline{\mathrm{SC}}: \mathrm{API}$ $R^{2}=0.81 ;$ Adj $R^{2}=0.78 ; F_{8.54}=28.3 ; p<0.001$ (N)RMSE $=0.13(12 \%)$
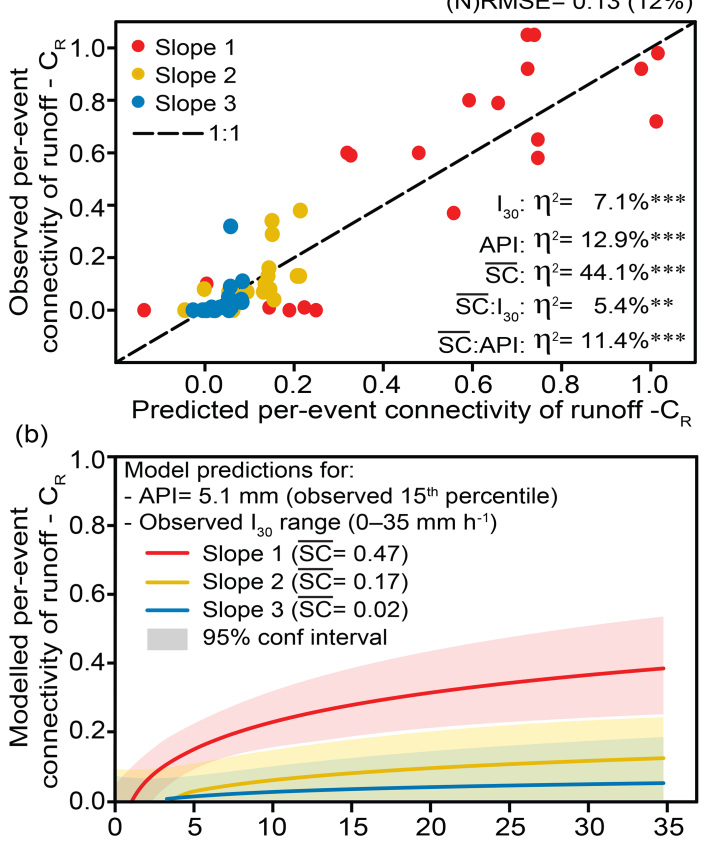

(c)

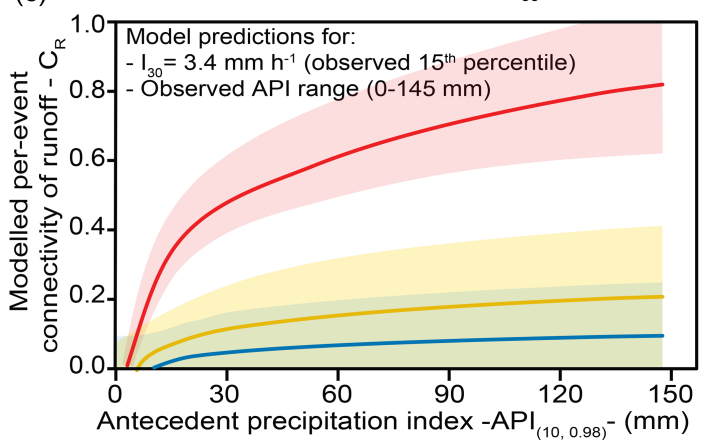

Figure 5. Structural and dynamic control of patch-scale to hillslopescale runoff connectivity: (a) best-supported model of runoff connectivity and corresponding observed-versus-predicted runoff connectivity values; (b) modelled $I_{30}$ and $\overline{\mathrm{SC}}$ effects on runoff connectivity (API is fixed at $5.1 \mathrm{~mm}, 15$ th percentile of observed API values); (c) modelled API and $\overline{\mathrm{SC}}$ effects on runoff connectivity ( $I_{30}$ is fixed at $3.4 \mathrm{~mm} \mathrm{~h}^{-1}, 15$ th percentile of observed values). The structure, $R^{2}$, Adj $R^{2}, F$ statistic, $p$ value and (normalized) root-mean-squared error of the best-supported model are detailed on top of the graph; $\eta^{2}$ values within the graph indicate the percent variance explained by the direct and interaction terms of the model. Significance: *** $p<0.001$; ** $p<0.01$; * $p<0.05$; "ns" not significant at $\alpha=0.05$. Note that $\dagger$ indicates that the model takes logtransformed values for the co-variables $I_{30}$ and API and that the graphs in panels (b) and (c) show back-transformed $I_{30}$ and API values for the modelled relationships.
Table 2. Spearman's $R$ correlations between the event characteristics and conditions (storm depth, Dp; rainfall duration, Rd; 15 and 30 min maximum rainfall intensity, $I_{15}$ and $I_{30}$; mean rainfall intensity, $I_{\mathrm{m}}$; and antecedent precipitation index, API) and the connectivity of runoff and sediments for the three experimental slopes.

\begin{tabular}{|c|c|c|c|}
\hline & & $\begin{array}{r}\text { Connectivity } \\
\text { of runoff }- \\
C_{\mathrm{R}}\end{array}$ & $\begin{array}{r}\text { Connectivity } \\
\text { of sediments - } \\
C_{\mathrm{S}}\end{array}$ \\
\hline \multirow{3}{*}{ Dp } & Slope 1 & $0.50 *$ & $0.21 \mathrm{~ns}$ \\
\hline & Slope 2 & $0.48^{*}$ & $0.19 \mathrm{~ns}$ \\
\hline & Slope 3 & $0.60^{* *}$ & $0.36 \mathrm{~ns}$ \\
\hline \multirow{3}{*}{$\mathrm{Rd}$} & Slope 1 & $0.23 \mathrm{~ns}$ & $-0.23 \mathrm{~ns}$ \\
\hline & Slope 2 & $0.18 \mathrm{~ns}$ & $-0.25 \mathrm{~ns}$ \\
\hline & Slope 3 & $0.45^{*}$ & $0.23 \mathrm{~ns}$ \\
\hline \multirow{3}{*}{$I_{15}$} & Slope 1 & $\mathbf{0 . 5 3} 3^{* *}$ & $\mathbf{0 . 7 8}^{* * *}$ \\
\hline & Slope 2 & $0.56^{* *}$ & $\mathbf{0 . 5 5}^{\text {** }}$ \\
\hline & Slope 3 & $0.51^{*}$ & $0.39 \mathrm{~ns}$ \\
\hline \multirow{3}{*}{$I_{30}$} & Slope 1 & $0.57^{* *}$ & $0.73^{* * *}$ \\
\hline & Slope 2 & $0.61^{* *}$ & $0.64^{* *}$ \\
\hline & Slope 3 & $0.57^{* *}$ & $0.43^{*}$ \\
\hline \multirow{3}{*}{$I_{\mathrm{m}}$} & Slope 1 & $0.54^{*}$ & $\mathbf{0 . 7 8}^{* * *}$ \\
\hline & Slope 2 & $0.65^{* *}$ & $0.67^{* * *}$ \\
\hline & Slope 3 & $0.50^{*}$ & $\mathbf{0 . 5 8}^{* *}$ \\
\hline \multirow{3}{*}{ API $(10 \mathrm{~d}, k=0.98)$} & Slope 1 & $0.79 * * *$ & $0.47^{*}$ \\
\hline & Slope 2 & $0.75^{* * *}$ & $0.46^{*}$ \\
\hline & Slope 3 & $0.75^{* * *}$ & $0.64^{* *}$ \\
\hline
\end{tabular}

Significance: ${ }^{* * *} p<0.001 ;{ }^{* *} p<0.01$; * $p<0.05$; "ns" not significant at $\alpha=0.05$. Spearman's $R$ correlation values in bold are $\geq 0.50$.

for these poorly connected $(\overline{\mathrm{SC}} \leq 0.17)$ systems. Instead, $C_{\mathrm{R}}$ strongly increased with $I_{30}$ and API for the rilled-slope system (Slope 1), where runoff-producing low-cover areas showed a large spatial contiguity $(\overline{\mathrm{SC}}=0.47)$. Furthermore, antecedent precipitation had a higher impact compared to the influence of maximum rainfall intensity on runoff connectivity. In fact, $I_{30}$ displayed a limited impact on runoff connectivity under dry antecedent conditions (e.g. if API $=5.1 \mathrm{~mm}$, $C_{\mathrm{R}}$ in Slope 1 can increase up to $\sim 0.4$ for large $I_{30}$ values; Fig. 5b). Nevertheless, antecedent precipitation showed an efficient capacity to increase runoff connectivity, even for moderate- and low-intensity rainfall events (e.g. if $I_{30}=$ $3.4 \mathrm{~mm} \mathrm{~h}^{-1}, C_{\mathrm{R}}$ in Slope 1 may grow up to $\sim 0.8$ for large API values; Fig. 5 c).

The continuity of sediment fluxes across scales $\left(C_{\mathrm{S}}\right)$ strongly correlated with mean $\left(I_{\mathrm{m}}\right)$ and maximum $\left(I_{15}\right.$ and $I_{30}$ ) rainfall intensity, particularly for Slope 1 and Slope 2 (Table 2). Although considerably less intense, we also found significant correlations between $C_{\mathrm{S}}$ and antecedent precipitation (API). GLM modelling of $C_{\mathrm{S}}$ using these rainfall variables $\left(I_{\mathrm{m}}, I_{15}, I_{30}\right.$ and API) identified mean rainfall intensity $\left(I_{\mathrm{m}}\right)$, hillslope structural connectivity $(\overline{\mathrm{SC}})$ and their corresponding interaction term $\left(\overline{\mathrm{SC}}: I_{\mathrm{m}}\right)$ as the best model structure contributors for predicting sediment connectivity 
(a)
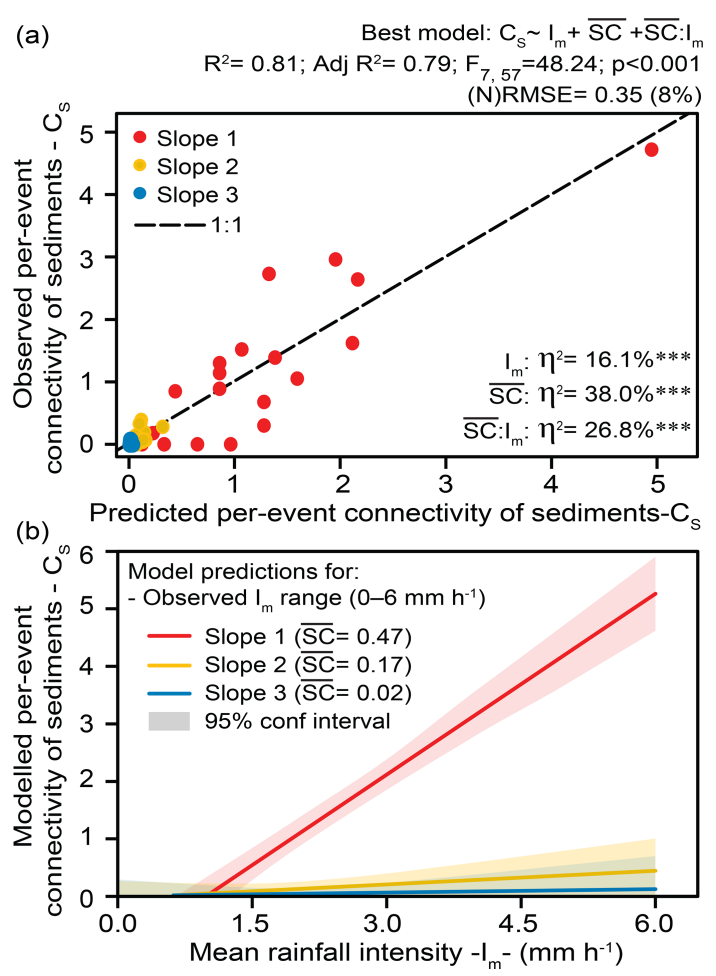

Figure 6. Structural and dynamic control of patch-scale to hillslopescale sediment connectivity: (a) best-supported model of sediment connectivity and corresponding observed-versus-predicted sediment connectivity values; (b) modelled $I_{\mathrm{m}}$ and $\overline{\mathrm{SC}}$ effects on runoff connectivity. The structure, $R^{2}$, Adj $R^{2}, F$ statistic, $p$ value and (normalized) root-mean-squared error of the best-supported model are detailed on top of the graph; $\eta^{2}$ values within the graph indicate the percent variance explained by the direct and interaction terms of the model. Significance: ${ }^{* * *} p<0.001$; ${ }^{* *} p<0.01$; ${ }^{*} p<0.05$; "ns" not significant at $\alpha=0.05$.

$\left(R^{2}=0.81\right.$, Adj $R^{2}=0.79$ and normalized $\mathrm{RMSE}=8 \% ;$ Fig. 6a). No additional increments of GLM complexity produced significant improvements of explained $C_{\mathrm{S}}$ variance (Adj $R^{2}$ values of alternative models in Table S4). Similarly to the best $C_{\mathrm{R}}$ model, the $\eta^{2}$ values for the optimal $C_{\mathrm{S}}$ model indicated a key influence of hillslope structural connectivity, which explained $38.0 \%$ and $26.8 \%$ of $C_{\mathrm{S}}$ variance for its direct $(\overline{\mathrm{SC}})$ and interaction $\left(\overline{\mathrm{SC}}: I_{\mathrm{m}}\right)$ effects, respectively (Fig. 6a). The direct effect of mean rainfall intensity explained an additional $16.1 \%$ of the observed $C_{\mathrm{S}}$ variance.

$C_{\mathrm{S}}$ increased linearly with mean rainfall intensity $\left(I_{\mathrm{m}}\right)$ for the three experimental slopes (Fig. 6b). However, the impact of rainfall intensity on the patch-scale to hillslope-scale continuity of sediment fluxes was highly dependent on the structural connectivity of these slope systems. For Slope 2 and Slope 3, with poorly connected low-cover areas that act as sediment sources $(\overline{\mathrm{SC}} \leq 0.17)$, increases of rainfall intensity along the observed $I_{\mathrm{m}}$ range $\left(0-6 \mathrm{~mm} \mathrm{~h}^{-1}\right)$ resulted in very small increases in sediment connectivity, pointing to a large within-slope redistribution of sediments for all the explored rainfall conditions. In stark contrast, for Slope 1, with a welldeveloped rill network that provides good structural connectivity of low-cover areas $(\overline{\mathrm{SC}}=0.47)$ and within-slope conditions for channel incision, $C_{\mathrm{S}}$ largely increased over 1 along the range of observed mean rainfall intensities, therefore reflecting large increases of unit-area sediment yield from the patch to the hillslope scales under high-intensity rainfall.

\section{Discussion}

Connectivity and scaling are key aspects for the understanding of hydrological and geomorphological processes in the continuum from small plots to hillslopes and catchments (Bracken and Croke, 2007; Sidle et al., 2017). In this study we shift from the very active, present conceptual discussion of the connectivity theory and their derived hydro-geomorphic study approaches (Wainwright et al., 2011; Bracken et al., 2013; Okin et al., 2015; Heckmann et al., 2018; Keesstra et al., 2018; Saco et al., 2020) to the practical application of the concepts of structural and functional connectivity for the analysis of the surface-patch to hillslope continuity of runoff and sediment fluxes in Mediterranean dry RMSSs.

\subsection{Structural connectivity: organization of vegetation patterns and rill networks}

Both vegetation distribution, which largely influences the spatial organization of patch hydro-sedimentary behaviour, and surface topography, which controls water and sediment flow direction, represent the major determinants for the potential transfer of water and sediments in the flow-path-based approach of structural connectivity applied in our study. Dryland vegetation is frequently organized in patches, ranging from barely to densely covered surfaces, which interact as interconnected source and sink areas of runoff and sediments (Puigdefabregas, 2005; Saco et al., 2020). This source and sink behaviour largely controls the within-slope retention of water and soil resources and has been extensively described as a key structural control for the production and routing of runoff and sediments in both natural Mediterranean semiarid landscapes (Puigdefabregas et al., 1999; Cammeraat, 2004; Arnau-Rosalen et al., 2008; Mayor et al., 2011) and reclaimed Mediterranean dry systems (Moreno-de-las-Heras et al., 2009; Merino-Martín et al., 2012b, 2015; Espigares et al., 2013). Our results reveal that the hillslope position of densely vegetated patches is a significant factor affecting the structural connectivity of the analysed reclaimed slope systems. In our study, the preferential concentration of densely vegetated, sink patches in the middle and lower sections of Slope 3 considerably reduces the connectivity of source areas as compared to Slope 2, where the bottom of the slope is dominated mainly by poorly covered areas 
(Fig. 3b-d). These results agree with other empirical studies in the Mediterranean region that indicate that the presence of dense vegetation in and near the lower sections of plots and hillslopes provides a strong structural control for runoff and sediment delivery (Bautista et al., 2007; Boix-Fayos et al., 2007).

Our analysis of the structural components of connectivity suggests that rill networks are key elements for the transfer of water runoff and sediments. The densely developed rill network of Slope 1 acts as a dominant, primary factor enhancing the spatial contiguity between the barely covered, source areas distributed along the hillslope and the outlet of the experimental slope, very largely increasing the structural connectivity of the system (Fig. 3a and d). In fact, rill networks provide very efficient erosive flow-routing pathways that largely facilitate the transference of water and sediments across sections of the hillslopes with little or no potential for runoff reinfiltration and sediment deposition (Nicolau, 2002; Bracken and Crocke, 2007; Moreno-de-las-Heras et al., 2010; Wester et al., 2014; Lu et al., 2019).

\subsection{Functional connectivity: formation of connected runoff and sediment fluxes}

Rainfall characteristics and antecedent conditions dynamically interact with the range of structural elements of the hillslopes to enable or enhance connected flow. Our analysis reveals that maximum rainfall intensity and antecedent precipitation are the most relevant storm event factors providing dynamic control of surface-patch to hillslope continuity (or functional connectivity) of runoff (Fig. 5). Both maximum rainfall intensity and antecedent moisture conditions are commonly perceived as the main rainfall factors involved in the generation of runoff in Mediterranean landscapes (Calvo-Cases et al., 2003; Castillo et al., 2003; Cammeraat, 2004; Cantón et al., 2011; Mayor et al., 2011; Marchamalo et al., 2016; Martínez-Murillo et al., 2018; Rodríguez-Caballero et al., 2014). Infiltration-excess runoff triggered by high-intensity rainfall typically dominates the hydrological responses of Mediterranean hillslopes under dry conditions. Saturation-excess runoff may also occur in Mediterranean dry hillslopes, particularly on soils previously wetted by antecedent rainfall, inducing saturation of the top layer of the soil profile with moderate-intensity precipitation (Martínez-Mena et al., 1998; Puigdefabregas et al., 1999; Calvo-Cases et al., 2003; Castillo et al., 2003). The poor soil development conditions that characterize our reclaimed study sites may facilitate these two runoff generation mechanisms (Nicolau and Asensio, 2000; Moreno-de-las-Heras, 2009). Whilst rapid formation of surface crusts in barely covered patches of these reclaimed soils can largely facilitate the formation of infiltration-excess runoff, the massive structure of the soils, particularly in intermediate to deep layers showing moderate- to low-vegetation root activity, can also facilitate the formation of runoff from the temporary saturation of the top $(5-20 \mathrm{~cm})$ soil layer (Nicolau, 2002; Moreno-de-lasHeras et al., 2011a).

Our results also indicate a higher efficiency of antecedent precipitation than maximum rainfall intensity in providing conditions for the generation of patch-scale to hillslope-scale runoff continuity (Fig. 5b and c). Similarly, other Mediterranean dry hillslope and catchment studies have highlighted the primary role of antecedent precipitation on establishing spatial continuity in the generation and routing of runoff (Puigdefabregas et al., 1999; Fitzjohn et al., 1998; BoixFayos et al., 2007; Marchamalo et al., 2016). Under dry antecedent conditions, runoff generation is spatially heterogeneous due to the fine-scale spatial variation of infiltration capacity. This variability is generated by both patchy vegetation and soil variability, which promote large discontinuities in hydrological pathways inducing spatial isolation of runoffproducing areas (Calvo-Cases et al., 2003; Boix-Fayos et al., 2007). In contrast, wet conditions reduce soil infiltration capacity (Cerdà, 1997; Moreno-de-las-Heras et al., 2009) and blur the spatial variation in hydrological properties by facilitating the formation of runoff from the saturation of the top and subsoil layers (Puigdefabregas et al., 1999; Calvo-Cases et al., 2003), thus resulting in the increased spatial continuity of active hydrological pathways for both the generation of runoff and the transference of water among scales and elements of the landscapes (Fitzjohn et al., 1998; Boix-Fayos et al., 2007; Marchamalo et al., 2016). Our results suggest that $30-50 \mathrm{~mm}$ of precipitation accumulated over an antecedent period of $10 \mathrm{~d}$ can notably enhance the hydrological connectivity in our study slopes (Fig. 5c). These conditions mainly take place in the area during the autumn and spring seasons.

The structural connectivity of the studied slope systems largely controls the functional connectivity of the runoff responses to rainfall intensity and antecedent precipitation (Fig. 5b and c). In contrast to Slope 2 and Slope 3, where the low spatial contiguity of runoff source areas strongly limits the impact of rainfall conditions on runoff connectivity, the surface-patch to hillslope continuity of runoff is highly sensitive to rainfall intensity and antecedent precipitation in Slope 1 . The presence of a well-developed rill network in this slope strongly increases the structural connectivity of the system and provides a very efficient, preferential pathway for the routing of runoff. Modelling results by Reaney et al. (2014) explain the high efficiency of rill networks in the transmission of runoff as a function of their effects on transfer distances. Overall, rills operate as channels that reduce transfer distances in relation to effective contributing area, resulting in enhanced runoff transmission along the hillslope by an increased flow velocity and reduced length to flow concentration. In this study, the high runoff transmission efficiency of the rill networks can be illustrated by the resulting cross-scale runoff continuity responses observed in the experimental slopes during the most extremely connected events (top $C_{\mathrm{R}}$ whisker values in Fig. 4c), recorded in early June and November 2008 for rather large rainfall events with 
moderate intensities occurring under wet antecedent conditions ( $\sim 50 \mathrm{~mm}$ depth, $7-9 \mathrm{~mm} \mathrm{~h}^{-1} I_{30}$ and $35-45 \mathrm{~mm}$ API). In such conditions, the high runoff transmission efficiency of the rill network in Slope 1 results in the complete transference of patch-scale generated runoff to the outlet of the system, largely differing from the poorly established hydrological connectivity of the two non-rilled slopes, where $60 \%-$ $70 \%$ of path-scale runoff is re-infiltrated downslope before reaching the outlet.

Besides the key influence of rills for the spatial transmission of runoff, these hillslope structural elements were also found to play a dominant role in the generation of sediment fluxes and its spatial distribution. Overall, our experimental slopes display two contrasting sedimentological behaviours that can be compared in light of our sediment connectivity results (Fig. 4b and d). While the two non-rilled slopes (Slope 2 and Slope 3) show, for all the events analysed, poorly connected sediment flows characterized by important sediment deposition between the surface-patch and hillslope scales, sediment yield can very largely increase (i.e. up to 5 times) with scale for the rilled system (Slope 1) when active rill incision takes place. Similarly, other studies carried out in Mediterranean landscapes indicate that sediment yield generally decreases from the small-plot to the hillslope scales in the absence of rills due to the loss of runoff by downslope reinfiltration, while soil loss per unit area generally increases with plot length when rill erosion processes prevail (BoixFayos et al., 2006; Bargarello and Ferro, 2010; Moreno-delas-Heras et al., 2010; Cantón et al., 2011; Bargarello et al., 2018). In fact, runoff convergence in the rill networks provides these erosive elements with the capacity to produce very important amounts of sediments, frequently resulting in significant increases in sediment yield with slope length (Giménez and Govers, 2001; Govers et al., 2007; Moreno-delas-Heras et al., 2011b; Wester et al., 2014; Lu et al., 2019). In this context, rills not only facilitate the within-slope transference of water and sediment fluxes but also work as powerful sources of sediments that can significantly contribute with freshly eroded particles to the analysed sediment fluxes between the surface-patch and hillslope scales.

Rainfall intensity emerges as the main storm property controlling the spatial continuity and scaling of sediment fluxes in our study slopes, particularly for the rilled system (Slope 1), where the ratio of hillslope to surface-patch sediment production (or functional connectivity of sediments) strongly increases with mean rainfall intensity (Fig. 6b). In Mediterranean hillslopes, storm intensity provides direct control on splash erosion and largely influences - through runoff production and concentration - the processes of sheet wash, sediment transport, and both rill and gully incision (Bargarello and Ferro, 2010; Moreno-de-las-Heras et al., 2010; Mayor et al., 2011; Cantón et al., 2011; Gallart et al., 2013). These links are frequently identified in the form of strong linear correlations between sediment yield and maximum (e.g. $I_{5}, I_{15}$ and $I_{30}$ ) rainfall intensity (e.g. Cammeraat,
2004; Rodríguez-Caballero et al., 2014). In the present study, sediment connectivity is better explained by mean rainfall intensity $\left(I_{\mathrm{m}}\right)$, which may suggest enhanced conditions for sediment transfer and rill incision by sustained (rather than maximum) high-intensity rainfall. However, the high correlation that links the maximum $\left(I_{30}\right)$ and mean $\left(I_{\mathrm{m}}\right)$ rainfall intensities of the analysed events (Pearson's $R=0.92 ; p<0.01$ ) reveals that the storms displaying the best conditions for the formation of spatially connected sediment flows along the study period (top $C_{\mathrm{S}}$ whisker values in Fig. 4d) were characterized by both high maximum and averaged rainfall intensity (up to 33 and $6 \mathrm{~mm} \mathrm{~h}^{-1}$ for $I_{30}$ and $I_{\mathrm{m}}$, respectively). These enhanced conditions for the production and routing of sediments were recorded during the summer season, in the form of high-intensity convective rainfall. Previous erosion research in this experimental site has highlighted the erosive capacity of late-spring and summer convective storms, which are responsible for up to $80 \%$ of annual soil loss in the area (Nicolau, 1992; Moreno-de-las-Heras et al., 2010; MerinoMartín et al., 2012a).

The frequently observed presence of thresholds and the non-linear character of landscape hydro-geomorphological responses are to a large extent related to the runoff and sediment connectivity that are responsible for transferring surface fluxes of resources from the small-plot and surfacepatch scales to broader hillslope and catchment scales (Puigdefabregas et al., 1999; Cammeraat, 2004; Bracken and Croke, 2007; Wainwright et al., 2011; Moreno-de-las-Heras et al., 2012; Sidle et al., 2017). Evidence of these dynamics is provided in this work by the non-linear relationships that link within-slope (functional) connectivity of runoff and sediment fluxes with the runoff coefficients and soil losses observed in the studied systems at the hillslope scale (Fig. 4e and f). Particularly, the critical loss of the capacity for redistributing surface fluxes by runoff re-infiltration and sediment deposition mechanisms in the analysed slope systems results in very large increases in hillslope-scale runoff production and soil loss. These non-linear hydro-geomorphological responses are strongly conditioned by the dynamics of Slope 1, where the presence of a well-organized rill network provides the system with cross-scale hillslope structural elements for intensive sediment production and effective flow routing.

Substantial increases in functional connectivity can dynamically feed back into the structural aspects of connectivity by modifying the spatial organization of preferential flow paths for the production and transmission of runoff and sediments (Turnbull et al., 2008; Wainwright et al., 2011; Okin et al., 2015; Turnbull and Wainwright, 2019). Structural connectivity is perceived in our study as a static property of the explored systems during the entire period of analysis (October 2007 to December 2008), which took place after 20 years of landscape evolution from the initial slope reclamation stage. Changes in structural connectivity of these Mediterranean dry human-made systems can be particularly important during earlier stages (first 5-10 years) of landscape 
evolution, when the spatial arrangement and redistribution of runoff and sediment fluxes largely shape the initial establishment and further dynamics of both vegetation patterns and rill networks (Nicolau and Asensio, 2000; Moreno-delas-Heras et al., 2011b). In fact, the rill network of Slope 1 represents a key factor determining the high structural connectivity of this system, but its own existence can be attributed to the development of high levels of (runoff and sediment) functional connectivity during the early stages of landscape evolution. Spatially explicit modelling frameworks of co-evolving landforms and vegetation patterns (e.g. Saco et al., 2020) may facilitate further exploration of the long-term dynamic feedbacks that link functional and structural connectivity.

\section{Conclusions}

We developed in this study a practical application of the conceptual elements of structural and functional connectivity for the analysis of the surface-patch to hillslope transmission of runoff and sediments in three Mediterranean dry reclaimed mining slope systems showing different levels of long-term development of vegetation and rill networks. Our results revealed an important role of the hillslope position of vegetation patches on the distribution of potential runoff and sediment flow paths. More critically, the rill networks emerged as key elements of structural connectivity in the slopes, providing preferential pathways that dominate the production, spatial organization and routing of the fluxes of water and sediments. On the other hand, both runoff and sediments were largely redistributed within the analysed slope systems in the absence of rill networks. The interactions between the structural connectivity of the experimental slopes and both antecedent precipitation and rainfall intensity largely controlled event functional connectivity. The results showed that rainfall intensity and, more importantly, antecedent precipitation largely increased the spatial continuity of runoff fluxes under rilled-slope conditions, where active rill incision under high-intensity rainfall induced large non-linear increases in hillslope-scale sediment yield.

In sum, this study provides empirical evidence of the feasibility of using the hydrological-connectivity concept for practical applications, specifically remarking on its usefulness for understanding how hillslope structural elements dynamically interact with storm characteristics and rainfall conditions to generate spatially continuous runoff and sediment fluxes. Overall, our study approach of structural and functional connectivity offers a useful framework for assessing the complex links and controlling factors that regulate the generation and movement of runoff and sediments across different scales and elements of the landscape in Mediterranean dry and other water-limited environments.
Data availability. The full hydro-sedimentary and precipitation data applied in this study can be found in Table S2. Other associated data are available upon request.

Supplement. This online supplement contains complementary information on general site characteristics (Table S1), the rainfall and hydrological data records of the analysed events (Table S2), the full model configurations applied for the analysis of runoff and sediment connectivity (Tables S3 and S4, respectively), and supplementary details on the parameterization of the antecedent precipitation index (API) applied in this study (Sect. S1). The supplement related to this article is available online at: https://doi.org/10.5194/hess-242855-2020-supplement.

Author contributions. All the authors participated in the design of the study. LMM obtained the field data, with contributions from MMdlH, JMN and TE. Data preprocessing and analysis was performed by MMdlH and LMM. MMdlH led the writing of the paper, with significant contributions from all co-authors.

Competing interests. The authors declare that they have no conflict of interest.

Acknowledgements. Mariano Moreno-de-las-Heras acknowledges support from The University of Newcastle (Australia) through an International Research Visit fellowship developed in summer 2017 that facilitated the initial discussion and further development of this study. The field collection of the runoff and sediment yield data used in this study was supported by a $\mathrm{PhD}$ scholarship awarded to Luis Merino-Martín by the University of Alcalá. We are grateful to the Spanish National Geographical Institute and particularly to Juan M. Rodriguez, for granting us access to the PNOA aerial images for this study. We thank José A. Merino for his help in the development of the topographical field survey and DEM associated products and Jesús Romero for language corrections. We also thank two anonymous reviewers for their thoughtful comments on a previous version of this study.

Financial support. This research has been supported by the Ministerio de Ciencia, Innovación y Universidades (Spain) (grant nos. IJC-2015-26463 and CGL2010-21754-C02-02), the Australian Research Council (grant no. DP140104178) and the Comunidad Autónoma de Madrid (Spain) (grant no. S2009AMB-1783).

We acknowledge support of the publication fee by the CSIC Open Access Publication Support Initiative through its Unit of Information Resources for Research (URICI).

Review statement. This paper was edited by Erwin Zehe and reviewed by two anonymous referees. 


\section{References}

Akaike, H.: A new look at the statistical model identification, IEEE T. Automat. Control, 19, 716-723, https://doi.org/10.1109/TAC.1974.1100705, 1974.

Anderson, G. L., Hanson, J. D., and Haas, R. H.: Evaluating Landsat thematic Mapper derived vegetation indices for estimating above-ground biomass on semiarid rangelands, Remote Sens. Environ., 45, 165-175, https://doi.org/10.1016/00344257(93)90040-5, 1993.

Arnau-Rosalén, E., Calvo-Cases, A., Boix-Fayos, C., Lavee, H., and Sarah, P.: Analysis of soil surface component patterns affecting runoff generation, an example of methods applied to Mediterranean slopes in Alicante (Spain), Geomorphology, 101, 595606, https://doi.org/10.1016/j.geomorph.2008.03.001, 2008.

Bargarello, V. and Ferro, V.: Analysis of soil loss data from plots of differing length for the Sparacia experimental area, Sicily, Italy, Biosyst. Eng., 105, 411-422, https://doi.org/10.1016/j.biosystemseng.2009.12.015, 2010.

Bargarello, V., Ferro, V., Keesstra, S., Rodrigo-Comino, J., Pulido, M., and Cerdà, A.: Testing simple scaling in soil erosion processes at plot scale, Catena 167, 171-180, https://doi.org/10.1016/j.catena.2018.04.035, 2018.

Bautista, S., Mayor, A. G., Bourakhouadar, J., and Bellot, J.: Plant spatial pattern predicts slope runoff and erosion in a semiarid Mediterranean landscape, Ecosystems, 10, 987-998, https://doi.org/10.1007/s10021-007-9074-3, 2007.

Boix-Fayos, C., Martínez-Mena, M., Arnau-Rosalén, E., Calvo-Cases, A., Castillo, V., and Albadalejo, J.: Measuring soil erosion by field plots: Understanding the sources of variation, Earth-Sci. Rev., 78, 267-285, https://doi.org/10.1016/j.earscirev.2006.05.005, 2006.

Boix-Fayos, C., Martínez-Mena, M., Calvo-Cases, A., ArnauRosalén, E., Albadalejo, J., and Castillo, V.: Causes and underlying processes of measurement variability in field erosion plots in Mediterranean conditions, Earth Surf. Proc. Land., 32, 85-101, https://doi.org/10.1002/esp.1382, 2007.

Bracken, L. J. and Croke, J.: The concept of hydrological connectivity and its contribution to understanding runoffdominated geomorphic systems, Hydrol. Process., 21, 17491763, https://doi.org/10.1002/hyp.6313, 2007.

Bracken, L. J., Wainwright, J., Ali, G. A., Tetzlaff, D., Smith, M. W., Reaney, S. M., and Roy, A. G.: Concepts of hydrological connectivity: Research approaches, pathways and future agendas, Earth-Sci. Rev., 119, 17-34, https://doi.org/10.1016/j.earscirev.2013.02.001, 2013.

Calvo-Cases, A., Boix-Fayos, C., and Imeson, A. C.: Runoff generation, sediment movement and soil water behaviour on calcareous (limestone) slopes of some Mediterranean environments in southeast Spain, Geomorphology, 50, 269-291, https://doi.org/10.1016/S0169-555X(02)00218-0, 2003.

Cammeraat, E. L. H.: Scale dependent thresholds in hydrological and erosion response of a semi-arid catchment in southeast Spain, Agr. Ecosyst. Environ., 104, 317-332, https://doi.org/10.1016/j.agee.2004.01.032, 2004.

Cantón, Y., Solé-Benet, A., de Vente, J., Boix-Fayos, C., CalvoCases, A., Asensio, C., and Puigdefabregas, J.: A review of runoff generation and soil erosion across scales in semiarid south-eastern Spain, J. Arid Environ., 75, 1254-1261, https://doi.org/10.1016/j.jaridenv.2011.03.004, 2011.
Castillo, V. M., Gómez-Plaza, A., and Martínez-Mena, M.: The role of antecedent soil water content in the runoff response of semiarid catchments: a simulation approach, J. Hydrol., 284, 114 130, https://doi.org/10.1016/S0022-1694(03)00264-6, 2003.

Cerdà, A.: Seasonal changes of the infiltration rates in a Mediterranean scrubland on limestone, J. Hydrol., 198, 209-225, https://doi.org/10.1016/S0022-1694(96)03295-7, 1997.

Christensen, R.: Plane Answers to Complex Questions: The Theory of Linear Models, Springer, New York, 2002.

Espigares, T., Moreno-de-las-Heras, M., and Nicolau, J. M.: Performance of vegetation in reclaimed slopes affected by soil erosion, Restor. Ecol., 19, 35-44, https://doi.org/10.1111/j.1526100X.2009.00546.x, 2011.

Espigares, T., Merino-Martín, L., Moreno-de-las-Heras, M., and Nicolau, J. M.: Intensity of ecohydrological interactions in reclaimed Mediterranean slopes: effects of run-off redistribution on plant performance, Ecohydrology, 6, 836-844, https://doi.org/10.1002/eco.1307, 2013.

Fitzjohn, C., Ternan, J. L., and Williams, A. G.: Soil moisture variability in a semi-arid gully catchment: implications for runoff and erosion control, Catena, 32, 55-70, https://doi.org/10.1016/S0341-8162(97)00045-3, 1998.

Gallart, F., Pérez-Gallego, N., Latron, J., Catari, G., MartínezCarreras, N., and Nord, G.: Short- and long-term studies of sediment dynamics in a small humid mountain Mediterranean basin with Badlands, Geomorphology, 196, 242-251, https://doi.org/10.1016/j.geomorph.2012.05.028, 2013.

Geib, H. V.: A new type of installation for measuring soil and water losses from control plots, Agron. J., 25, 429-440, 1933.

Gerlach, T.: Hillslope troughs for measuring sediment movement, Revue de Géomorphologie Dynamique, 17, 173-175, 1967.

Giménez, R. and Govers, G. Interaction between bed roughness and flow hydraulics in eroding rills, Water Resour. Res., 37, 791-799, https://doi.org/10.1029/2000WR900252, 2001.

Govers, G., Giménez, R., and Van Oost, K.: Rill erosion: exploring the relationship between experiments, modeling and field observations, Earth-Sci. Rev., 84, 87-102, https://doi.org/10.1016/j.earscirev.2007.06.001, 2007.

Hardy, R., James, M. R., Plates, J. M., and Quinton, J. N.: Using real time particle tracking to understand soil particle movements during rainfall events, Catena, 150, 32-38, https://doi.org/10.1016/j.catena.2016.11.005, 2017.

Hargreaves, G. H. and Samani, Z. A.: Reference crop evapotranspiration from temperature, Appl. Eng. Agricult., 1, 96-99, https://doi.org/10.1016/j.catena.2016.11.005, 1985.

Heckmann, T., Cavalli, M., Cerdan, O., Foerster, S., Javaux, M., Lode, E., Smetanová, A., Vericat, D., and Brardinoni, F.: Indices of sediment connectivity: opportunities, challenges and limitations, Earth-Sci. Rev., 187, 77-108, https://doi.org/10.1016/j.earscirev.2018.08.004, 2018.

Keesstra, S., Nunes, J. P., Saco, P., Parsons, T., Poeppl, R., Masselink, R., and Cerdà, A.: The way forward: Can connectivity be useful to design better measuring and modelling schemes for water and sediment dynamics?, Sci. Total Environ., 644, 15571572, https://doi.org/10.1016/j.scitotenv.2018.06.342, 2018.

Kohler, M. A. and Linsley, R. K.: Predicting the runoff from storm rainfall, Weather Bureau Research Papers 34, US Department of Commerce, Washington, 1951. 
López-Martín, F., Cabrera, M., and Cuadrat-Prats, J. M.: Atlas Climático de Aragón, Gobierno de Aragón, Zaragoza, 2007.

Lu, X., Li, Y., Washington, R. A., and Li, Y.: Structural and sedimentological connectivity on a rilled hillslope, Sci. Total Environ., 655, 1479-1494, https://doi.org/10.1016/j.scitotenv.2018.11.137, 2019.

Marchamalo, M., Hooke, J. M., and Sandercock, P. J.: Flow and sediment connectivity in semi-arid landscapes in SE Spain: patterns and controls, Land Degrad. Dev., 27, 1032-1044, https://doi.org/10.1002/ldr.2352, 2016.

Martínez-Mena, M., Albaladejo, J., and Castillo, V. M.: Factors influencing surface runoff generation in a Mediterranean semi-arid environment: Chicamo watershed, SE Spain, Hydrol. Process., 12, 741-754, https://doi.org/10.1002/(SICI)10991085(19980430)12:5<741::AID-HYP622>3.0.CO;2-F, 1998.

Martínez-Murillo, J. F., Hueso-Gonzalez, P., and Ruiz-Sinoga, J. D.: Impact of low pressure grazing on the hydrological and sediment connectivity in hillslopes under contrasted Mediterranean climatic conditions (South of Spain), Land Degrad. Dev., 29, 1130-1140, https://doi.org/10.1002/ldr.2809, 2018.

Martín-Moreno, C., Martín-Duque, J. F., Nicolau, J. M., Muñoz, A., and Zapico, I.: Waste dump erosional landform stability - a critical issue for mountain mining, Earth Surf. Proc. Land., 43, 1431-1450, https://doi.org/10.1002/esp.4327, 2018.

Masselink, R. J. H., Temme, A. J. A. M., Giménez, R., Casali, J., and Keesstra, S. D.: Assessing slope-channel connectivity in an agricultural catchment using rare-earth oxide tracers and random forest models, Geogr. Res. Lett., 43, 19-39, https://doi.org/10.18172/cig.3169, 2017a.

Masselink, R. J. H., Heckmann, T., Temme, A. J. A. M., Anders, N. S., Gooren, H. P. A., and Keesstra, S. D.: A network theory approach for a better understanding of overland flow connectivity, Hydrol. Process., 31, 207-220, https://doi.org/10.1002/hyp.10993, 2017 b.

Mayor, A. G., Bautista, S., Small, E., Dixon, M., and Bellot, J.: Measurement of the connectivity of runoff source areas as determined by vegetation pattern and topography: A tool for assessing potential water and soil losses in drylands, Water Resour. Res., 44, W10423, https://doi.org/10.1029/2007WR006367, 2008.

Mayor, A. G., Bautista, S., and Bellot, J.: Scale-dependent variation in runoff and sediment yield in a semiarid Mediterranean catchment, J. Hydrol., 397, 128-135, https://doi.org/10.1016/j.jhydrol.2010.11.039, 2011.

Merino-Martín, L., Moreno-de-las-Heras, M., Pérez-Domingo, S., Espigares, T., and Nicolau, J. M.: Hydrological heterogeneity in Mediterranean reclaimed slopes: runoff and sediment yield at the patch and slope scales along a gradient of overland flow, Hydrol. Earth Syst. Sci., 16, 1305-1320, https://doi.org/10.5194/hess-161305-2012, 2012a.

Merino-Martín, L., Breshears, D. D., Moreno-de-las-Heras, M., Villegas, J. C., Pérez-Domingo, S., Espigares, T., and Nicolau, J. M.: Ecohydrological interrelationships between vegetation patches and soil hydrological properties along a disturbance gradient: How sources and sinks of runoff determine a restoration threshold, Restor. Ecol., 20, 360-368, https://doi.org/10.1111/j.1526100X.2011.00776.x, 2012b.

Merino-Martín, L., Moreno-de-las-Heras, M., Pérez-Domingo, S., Espigares, T., and Nicolau, J. M.: Overland flow directs soil moisture and ecosystem processes at patch scale in Mediterranean restored slopes, Catena, 133, 71-84, https://doi.org/10.1016/j.catena.2015.05.002, 2015.

Moreno-de-las-Heras, M.: Development of soil physical structure and biological functionality in mining spoils affected by soil erosion in a Mediterranean-Continental environment, Geoderma, 149, 249-256, https://doi.org/10.1016/j.geoderma.2008.12.003, 2009.

Moreno-de-las-Heras, M., Merino-Martín, L., and Nicolau, J. M.: Effect of vegetation cover on the hydrology of reclaimed mining soils under Mediterranean-continental climate, Catena, 77, 3947, https://doi.org/10.1016/j.catena.2008.12.005, 2009.

Moreno-de-las-Heras, M., Nicolau, J. M., Merino-Martín, L., and Wilcox, B. P.: Plot-scale effects on runoff and erosion along a slope degradation gradient, Water Resour. Res., 46, W04503, https://doi.org/10.1029/2009WR007875, 2010.

Moreno-de-las-Heras, M., Espigares, T., Merino-Martín, L., and Nicolau, J. M.: Water-related ecological impacts of rill erosion processes in Mediterranean-dry reclaimed slopes, Catena, 84, 114-124, https://doi.org/10.1016/j.catena.2010.10.010, $2011 \mathrm{a}$.

Moreno-de-las-Heras, M., Díaz-Sierra, R., Nicolau, J. M., and Zavala, M. A.: Evaluating restoration of man-made slopes: a threshold approach balancing vegetation and rill erosion, Earth Surf. Proc. Land., 36, 1367-1377, https://doi.org/10.1002/esp.2160, 2011b.

Moreno-de-las-Heras, M., Saco, P. M., Willgoose, G. R., and Tongway, D. J.: Variations in hydrological connectivity indicate abrupt changes in rainfall-use efficiency of vegetation, J. Geophys. Res., 117, G03009, https://doi.org/10.1029/2011JG001839, 2012.

Moreno-de-las-Heras, M., Gallart, F., Latron, J., Martínez-Carreras, N., Ferrer, L., and Estrany, J.: Testing the use of ${ }^{210} \mathrm{~Pb}_{\mathrm{ex}}$ to study sediment connectivity in a Mediterranean mountain basin with badlands, Land Degrad. Dev., 29, 676-689, https://doi.org/10.1002/ldr.2712, 2018.

Moreno-de-las-Heras, M., Lindenberger, F., Latron, J., LanaRenault, N., Arnáez, J., Romero-Díaz, A., and Gallart, F.: Hydrogeomorphological consequences of the abandonment of agricultural terraces in the Mediterranean región: Key controlling factors and landscape stability patterns, Geomorphology, 333, 7391, https://doi.org/10.1016/j.geomorph.2019.02.014, 2019.

Nicolau, J. M.: Evolución geomorfológica de taludes de escombreras en ambiente mediterráneo-continental, Teruel, $\mathrm{PhD}$ Thesis, Universidad Autónoma de Madrid, Madrid, 1992.

Nicolau, J. M.: Runoff generation and routing on artificial slopes in a Mediterranean-continental environment: the Teruel coalfield, Spain, Hydrol. Process., 16, 631-647, https://doi.org/10.1002/hyp.308, 2002.

Nicolau, J. M. and Asensio, E.: Rainfall erosion on opencast coalmine lands: ecological perspective, in: Reclaimed Land: Erosion Control, Soils and Ecology, edited by: Haigh, M. J., Balkema, Rotterdam, 51-73, 2000.

O'Callaghan, J. F. and Mark, D. M.: The extraction of drainage networks from digital elevation data, Comput. Vis. Graph Image Proc., 28, 323-344, https://doi.org/10.1016/S0734189X(84)80011-0, 1984.

Okin, G. S., Moreno-de-las-Heras, M., Saco, P. M., Throop, H. L., Vivoni, E. R., Parsons, A. J., Wainwright, J., and Peters, D. P. C.: Connectivity in dryland landscapes: shifting con- 
cepts of spatial interactions, Front. Ecol. Environ., 13, 20-27, https://doi.org/10.1890/140163, 2015.

Peña, J. L., Cuadrat, J. M., and Sánchez, M.: El Clima de la Provincia de Teruel, Instituto de Estudios Turolenses, Diputación Provincial de Teruel, Teruel, Spain, 2002.

Puigdefabregas, J.: The role of vegetation patterns in structuring runoff and sediment fluxes in drylands, Earth Surf. Proc. Land., 30, 133-147, https://doi.org/10.1002/esp.1181, 2005.

Puigdefagregas, J., Sole, A., Gutierrez, L., del Barrio, G., and Boer, M.: Scales and processes of water and sediment redistribution in drylands: results from the Rambla Honda field site in Southeast Spain, Earth-Sci. Rev., 48, 39-70, https://doi.org/10.1016/S0012-8252(99)00046-X, 1999.

R Core Team: R, A language and environment for statistical computing, R Foundation for Statistical Computing, Vienna, Austria, available at: https://www.r-project.org/, last access: December 2019.

Reaney, S. M., Bracken, L. J., and Kirkby, M. J.: The importance of surface controls on overland flow connectivity in semi-arid environments: results from a numerical experimental approach, Hydrol. Process. 28, 2116-2128, https://doi.org/10.1002/hyp.9769, 2014.

Rodríguez-Caballero, E., Cantón, Y., Lázaro, R., and Solé-Benet, A.: Cross-scale interactions between Surface components and rainfall properties. Non-linearities in the hydrological and erosive behavior of semiarid catchments, J. Hydrol., 517, 815-825, https://doi.org/10.1016/j.jhydrol.2014.06.018, 2014.

Saco, P. M., Rodríguez, J. F., Moreno-de-las-Heras, M., Keesstra, S., Azadi, S., Sandi, S., Baartman, J., RodrigoComino, J., and Rossi, M. J.: Using hydrological connectivity to detect transitions and degradation thresholds: application to dryland systems, Catena, 186, 104354, https://doi.org/10.1016/j.catena.2019.104354, 2020.
Scanlon, T. M., Caylor, K. K., Levin, S. A., and RodriguezIturbe, I.: Positive feedbacks promote power-law clustering of Kalahari vegetation, Nature, 449, 209-212, https://doi.org/10.1038/nature06060, 2007.

Sidle, R. C., Gomi, T., Loaiza-Usuga, J. C., and Jarihani, B.: Hydrogeomorphic processes and scaling issues in the continuum from soil pedons to catchments, Earth-Sci. Rev., 175, 75-96, https://doi.org/10.1016/j.earscirev.2017.10.010, 2017.

Turnbull, L. and Wainwright, J.: From structure to function: Understanding shrub encroachment in drylands using hydrological and sediment connectivity, Ecol. Indicat., 98, 608-618, https://doi.org/10.1016/j.ecolind.2018.11.039, 2019.

Turnbull, L., Wainwright, J., and Brazier, R. E.: A conceptual framework for understanding semiarid land degradation: ecohydrological interactions across multiple-space and time scales, Ecohydrology 1, 23-34, https://doi.org/10.1002/eco.4, 2008.

Turnbull, L., Wainwright, J., and Brazier, R. E.: Changes in hydrology and erosion over a transition from grassland to shrubland, Hydrol. Process., 24, 393-414, https://doi.org/10.1002/hyp.7491, 2010.

Wainwright, J., Turnbull, L., Ibrahim, T. G., Lexartza-Artza, I. Thornton, S. F., and Brazier, R.: Linking environmental regimes, space and time: interpretations of structural and functional connectivity, Geomorphology, 126, 387-404, https://doi.org/10.1016/j.geomorph.2010.07.027, 2011.

Wester, T., Wasklewicz, T., and Staley, D.: Functional and structural connectivity within a recently burned drainage basin, Geomorphology, 206, 362-373, https://doi.org/10.1016/j.geomorph.2013.10.011, 2014.

Yair, A. and Raz-Yassif, N.: Hydrological effects in a small arid catchment: scale effects of rainfall and slope length, Geomorphology, 61, 155-169, https://doi.org/10.1016/j.geomorph.2003.12.003, 2004. 